\title{
Population differentiation and historical demography of the threatened snowy plover Charadrius nivosus (Cassin, 1858)
}

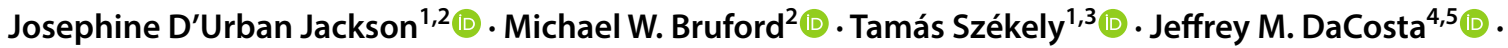

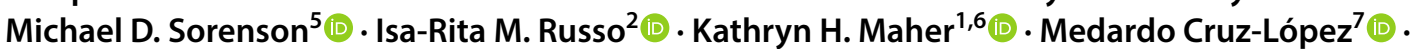 \\ Daniel Galindo-Espinosa ${ }^{8}$. Eduardo Palacios ${ }^{9}$ (]) Atahualpa Eduardo De Sucre-Medrano ${ }^{10}$. John Cavitt ${ }^{11}$.

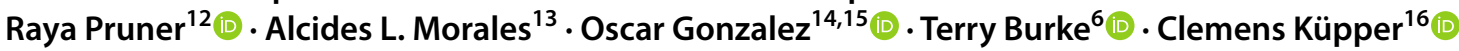

Received: 1 October 2019 / Accepted: 4 February 2020 / Published online: 28 February 2020

(c) The Author(s) 2020

\begin{abstract}
Delineating conservation units is a complex and often controversial process that is particularly challenging for highly vagile species. Here, we reassess population genetic structure and identify those populations of highest conservation value in the threatened snowy plover (Charadrius nivosus, Cassin, 1858), a partial migrant shorebird endemic to the Americas. We use four categories of genetic data-mitochondrial DNA (mtDNA), microsatellites, Z-linked and autosomal single nucleotide polymorphisms (SNPs) - to: (1) assess subspecies delineation and examine population structure (2) compare the sensitivity of the different types of genetic data to detect spatial genetic patterns, and (3) reconstruct demographic history of the populations analysed. Delineation of two traditionally recognised subspecies was broadly supported by all data. In addition, microsatellite and SNPs but not mtDNA supported the recognition of Caribbean snowy plovers (C. n. tenuirostris) and Floridian populations (eastern $C . n$. nivosus) as distinct genetic lineage and deme, respectively. Low migration rates estimated from autosomal SNPs $(m<0.03)$ reflect a general paucity of exchange between genetic lineages. In contrast, we detected strong unidirectional migration $(m=0.26)$ from the western into the eastern nivosus deme. Within western nivosus, we found no genetic differentiation between coastal Pacific and inland populations. The correlation between geographic and genetic distances was weak but significant for all genetic data sets. All demes showed signatures of bottlenecks occurring during the past 1000 years. We conclude that at least four snowy plover conservation units are warranted: in addition to subspecies nivosus and occidentalis, a third unit comprises the Caribbean tenuirostris lineage and a fourth unit the distinct eastern nivosus deme.
\end{abstract}

Keywords Charadrius nivosus $\cdot$ Microsatellite $\cdot \operatorname{ddRAD} \cdot \operatorname{mtDNA} \cdot$ Demography $\cdot$ Conservation units

\section{Introduction}

The delineation of conservation units such as evolutionary significant units (ESUs, Moritz 1994) and management units (MUs) can be highly nuanced. Such units can be difficult to define in practice because of similarities in species-specific

Electronic supplementary material The online version of this article (https://doi.org/10.1007/s10592-020-01256-8) contains supplementary material, which is available to authorized users.

Josephine D'Urban Jackson

josiedjackson@gmail.com

$\bowtie$ Clemens Küpper

ckuepper@orn.mpg.de

Extended author information available on the last page of the article ecology and life history traits that are likely to promote cohesion among populations across a broad landscape. For example, highly vagile taxa such as pelagic organisms and species capable of flight may have high rates of gene flow, and are therefore unlikely to have many reciprocally monophyletic groups based on their mitochondrial DNA (mtDNA) sequences (Crandall et al. 2000; Medina et al. 2018).

Traditionally, studies aiming to identify conservation units using genetics have sampled a small number of variable genetic loci such as mtDNA and/or microsatellites. However, a greater number of genetic markers increases the power to detect fine scale population structure, and hence, increases the reliability of defining conservation units and their associated characteristics such as past demographic changes and effective population sizes (Allendorf et al. 
2010; Funk et al. 2012; Shafer et al. 2015). Genomic methods, including restriction enzyme associated DNA sequencing (RAD-seq, Baird et al. 2008; Miller et al. 2007), produce data from hundreds or thousands rather than tens of loci distributed throughout the genome, and can reveal previously uncharacterised genetic structure (e.g. Ruegg et al. 2014; Saenz-Agudelo et al. 2015; Barth et al. 2017; Vendrami et al. 2017; Younger et al. 2017; Sadanandan et al. 2019). In doing so, genomic methods have enabled novel, high resolution identification of new management units in species of high conservation priority (Palsbøll et al. 2007; Kjeldsen et al. 2016; Peters et al. 2016; Barth et al. 2017; Younger et al. 2017). In addition, these methods have proven successful in corroborating previously proposed taxonomic or conservation units that were first identified using low-resolution genetic data (Mason and Taylor 2015; Attard et al. 2018; Doyle et al. 2018) or ecological variation (Lemay and Russello 2015; Prince et al. 2017).

Once defined, the vulnerability of different conservation units to population declines can be assessed, in part, by using genetic data to reconstruct past demographic changes (e.g. Carnaval et al. 2009; Palsbøll et al. 2013; Garrick et al. 2015; Shafer et al. 2015; Stoffel et al. 2018). Importantly, the accuracy of genetic demographic reconstructions can be enhanced with data from a larger number of loci (Shafer et al. 2015), as well as using multiple modelling methods to corroborate findings (Brüniche-Olsen et al. 2014).

The snowy plover, Charadrius nivosus (Cassin, 1858; Küpper et al. 2009), is one of the least abundant shorebird species endemic to the Americas, but also one of the most thoroughly studied. This iconic, partially migratory shorebird exhibits an unusual breeding system of sequential polyandry where females desert their families to re-mate with a new partner, and inhabits salt flats of alkaline lakes, coastal lagoons and sandy beaches (Warriner et al. 1986; Page et al. 2009; Eberhart-Phillips et al. 2017). Coastal populations can be made up of migratory and resident individuals, however, inland breeding populations tend to migrate during the winter towards coastal habitat (Page et al. 2009). In addition, both sexes occasionally undergo long within and between breeding season movements $(50-1140 \mathrm{~km}$; Stenzel et al. 1994). The snowy plover subspecies taxonomy is debated, with some authorities (Clements et al. 2018; del Hoyo et al. 2019) recognising two subspecies (Charadius nivosus nivosus and $C$. $n$. occidentalis), whereas, a third, $C$. n. tenuirostris (American Ornithologists' Union 1957; Funk et al. 2007), is currently recognised by the United States Fish and Wildlife Service (USFWS 2011) although this subspecies shows limited phenotypic distinction from $C$. n. nivosus (Funk et al. 2007). C. n. nivosus (nivosus herein) is found within the United States and Mexico, the core distribution of $C$. n. tenuirostris (tenuirostris herein) comprises the Caribbean Islands and Bermuda, whereas, $C$. $n$. occidentalis (occidentalis herein) is found along the west coast of South America from Colombia to Chile (Fig. 1).

The most recent genetic analysis of snowy plovers supported the recognition of three subspecies (nivosus, tenuirostris, occidentalis) and updated their geographic distributions (Funk et al. 2007). Specifically, snowy plovers breeding in Florida and along the Gulf of Mexico coast, which had been previously assigned to tenuirostris, were more genetically similar to other populations of nivosus (Funk et al. 2007) than to the island populations of tenuirostris. However, a more recent analysis based on microsatellite loci with additional sampling of Mexican populations showed that the eastern nivosus snowy plover population from Florida may be differentiated from western nivosus snowy plovers (D'Urban Jackson et al. 2017). Among the western snowy plover populations, molecular analyses did not support distinct conservation units between the Pacific coast and inland populations (Funk et al. 2007; D'Urban Jackson et al. 2017). Despite this genetic evidence, the conservation status of Pacific snowy plovers as a distinct population segment under the Endangered Species Act has been maintained because available banding data have not

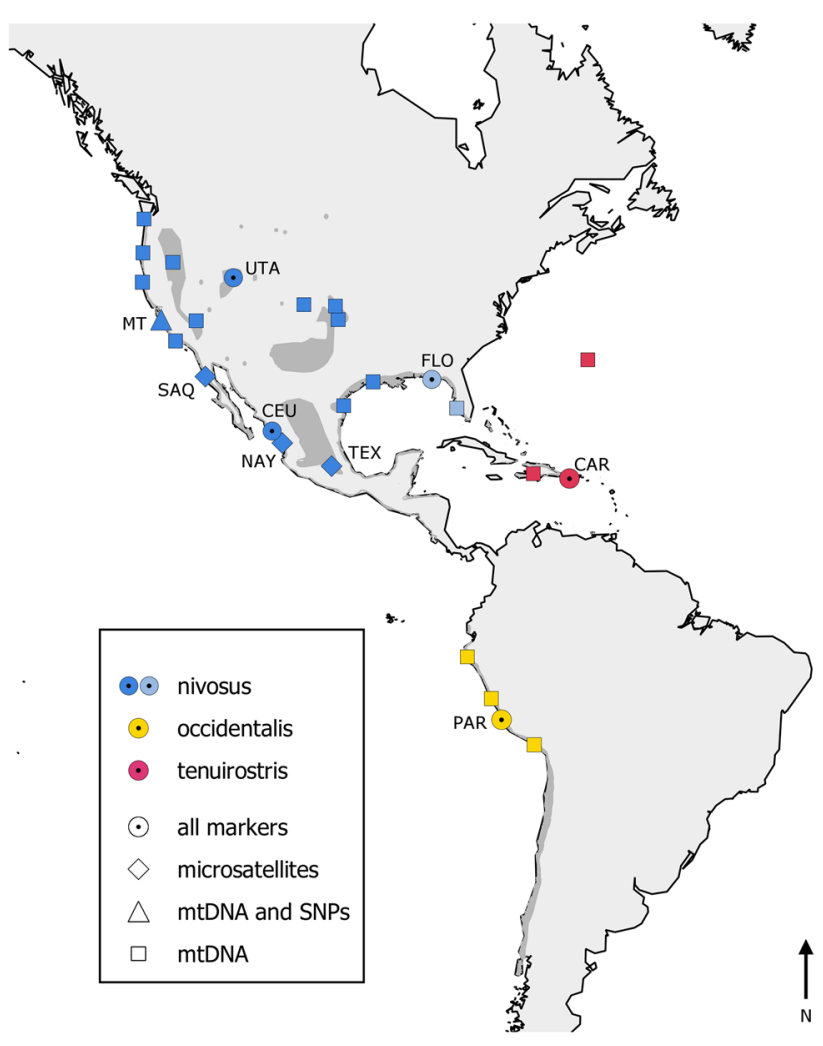

Fig. 1 Sampling locations of snowy plovers (Charadrius nivosus) included in each of the four genetic datasets (see legend). Deme identity is given by colour (blue: western nivosus, light blue: eastern nivosus, red: tenuirostris, yellow: occidentalis). Species range is indicated in dark grey shading. For details on sample sizes see Table 1 (all markers) and Table S2 (mtDNA only) 
confirmed movement between inland and coastal sites (Haig et al. 2011). Genetic homogeneity of western populations may be the result of gene flow from long distance breeding dispersal of females (D'Urban Jackson et al. 2017), which has been observed in Pacific populations (Stenzel et al. 1994). Overall, previous molecular studies using microsatellites and mtDNA sequences indicate low genetic diversity across all snowy plover subspecies (Funk et al. 2007; D'Urban Jackson et al. 2017). Furthermore, inbreeding has been detected in a small isolated population of snowy plovers through a long-term pedigree study (Colwell and Pearson 2011).

The estimated census breeding population sizes of the three subspecies are 25,869 (nivosus Thomas et al. 2012,), 1000-10,000 (occidentalis, Wetlands International 2019) and $<100$ (tenuirostris, Elliot-Smith et al. 2004; Brown 2012). Many coastal populations are declining because of habitat deterioration and human disturbance (Colwell et al. 2007; Küpper et al. 2011; Powell and Collier 2011; Page et al. 2009; Thomas et al. 2012; Cohen et al. 2014; GalindoEspinosa and Palacios 2015; Cruz-López et al. 2017). As a result, many populations are protected by federal and/ or state-level statutes (Haig et al. 2011; Cohen et al. 2014; Galindo-Espinosa and Palacios 2015). Population viability models suggest that the decline of coastal populations will become more severe throughout the species' range without intensive conservation management (Aiello-Lemmens et al. 2011; Eberhart-Phillips and Colwell 2014; Cruz-López et al. 2017). Furthermore, climate change might exacerbate risks of local extinctions due to rising sea levels and changes in the dynamics of tropical cyclone events, which are important for creating suitable nesting habitats (Aiello-Lemmens et al. 2011; Convertino et al. 2011).

Snowy plover breeding habitat includes sandy beaches, making the conservation management of this species in North America controversial, as habitat protection often conflicts with development and recreational activities (Lafferty et al. 2006). Regular reassessment of population structure in snowy plovers by implementing current methodological advances is therefore required to guide effective conservation policy. Both previous genetic analyses (Funk et al. 2007; D'Urban Jackson et al. 2017) used $\leq 15$ nuclear loci, which may have been insufficient to detect fine scale population structure in this highly vagile species. Here, we comprehensively re-evaluate genetic differentiation among snowy plover populations using four different genetic data sets: mtDNA, microsatellites, autosomal and Z-linked single-nucleotide polymorphisms (SNPs), respectively. We use these data to: (1) examine genetic support for the current subspecies delineation, examine population structure within the most widespread subspecies nivosus and identify putative distinct conservation units based on genetic data; (2) compare the sensitivity of the four different types of genetic data to detect fine scale genetic structure and spatial genetic patterns among controversial population segments; and (3) reconstruct the demographic history of snowy plover populations using three modelling methods to understand the origin of low genetic diversity.

\section{Materials and methods}

Combining previously published (Funk et al. 2007; Küpper et al. 2009; D'Urban Jackson et al. 2017) and newly collected data, we gathered genetic data from all three proposed subspecies (genetic lineages herein): nivosus, occidentalis, and tenuirostris. Sampling sites represented in each genetic dataset are shown in Fig. 1 and sample information is summarised in Table 1, with a more detailed description of each data set below.

\section{mtDNA}

We downloaded available snowy plover sequences of the mitochondrial D-loop (control region) from GenBank $(n=114$; Table $\mathrm{S} 1)$. In addition, we sequenced the D-loop for 67 new samples using primers and polymerase chain reaction (PCR) conditions described in Küpper et al. (2012). We aligned all sequences using the ClustalW alignment tool in BioEdit v7.2.5 (Hall 1999) and trimmed the alignment to 424 base pairs (bp) for downstream analyses. For clarity, only locations with both mtDNA and additional genetic information (microsatellites or single nucleotide polymorphism markers [SNPs]) are presented in Table 1 and Fig. 1. Details for mtDNA only samples, including GenBank accession numbers, are given in Table S1.

\section{Microsatellites}

Additional samples from occidentalis $(n=18)$ and tenuirostris $(n=13)$ were added to those described in the microsatellite dataset for nivosus published by D'Urban Jackson et al. (2017, $n=146$ ). We genotyped all samples at 15 microsatellite loci (including seven additional loci in comparison to D'Urban Jackson et al. (2017)) and removed first order relatives from the data set based on field records, i.e. we retained only one chick per brood. Primers, PCR conditions and reagents are described in Küpper et al. $(2008,2009)$ and D'Urban Jackson et al. (2017).

\section{Autosomal and Z-linked SNPs}

We extracted DNA from blood samples using the phenol-chloroform extraction method (Sambrook and Russell 2006). We prepared a multiplexed fragment library for double digest restriction site associated DNA sequencing 
(ddRAD) for 47 samples following the protocol described by DaCosta and Sorenson (2014) using EcoRI and SbfI restriction enzymes and adaptors incorporating an individual $6 \mathrm{bp}$ barcode. The multiplexed library was paired-end sequenced (100 bp reads) on one lane of an Illumina HiSeq 2000 platform in the Bauer Core Facility at Harvard University.

\section{Bioinformatics pipeline}

We discarded the paired read to simplify downstream data processing and checked the quality of the raw single-end reads using FastQC (v.0.11.5; Babraham Bioinformatics; https://www.bioinformatics.babraham.ac.uk/projects/fastq c/). Using the ddRAD software pipeline created by DaCosta and Sorenson (2014; https://github.com/BU-RAD-seq/), we first de-multiplexed sequences based on their unique barcodes. For each individual, we condensed identical sequences while maintaining a count of the sequences, and then filtered low quality, singleton sequences using the UCLUST function in USEARCH v5 (Edgar 2010). Condensed and filtered reads across all samples were then clustered at an $85 \%$ identity level using UCLUST. We compared the highest quality sequence from each cluster to the closest available reference genome (killdeer Charadrius vociferous Zhang et al. 2014,) using BLASTN (Altschul et al. 1990) and then combined clusters with identical or nearly identical hits. We aligned sequences within each cluster (i.e. putative locus) using MUSCLE v3 (Edgar 2004a, b). Finally, we scored genotypes for each individual at each locus using the python script RADgenotypes.py.

We flagged individual genotypes that had: (i) fewer than three reads, (ii) an uneven ratio between two alleles, with the minor allele having a proportion less than 0.3 (if unique across all samples) or 0.2 , and (iii) "extra" reads appearing with a proportion $\geq 0.1$, implying the presence of more than two alleles. We removed clusters if they: (i) had more than five samples with flagged genotypes, (ii) had a length $<19 \mathrm{bp}$, (iii) had a median per-sample depth less than 9.5, or (iv) had more than five samples with missing data. Clusters with potential alignment errors (see manual at https://github.com/BU-RAD-seq/ddRAD-seq-Pipeline) were also removed, as were clusters with $>4$ SNPs/indels, indels of length $>4 \mathrm{bp}$, and very high read depths (> 800 reads total across all individuals), as these characteristics may be indicative of multiple genomic loci being clustered together.

\section{Z-linked RAD loci}

We identified SNPs on the Z chromosome using a two-step method. First, we compared mean read depths for males and females for each quality filtered RAD locus, with the underlying expectation that sequencing depth for female samples should be about half that of male samples for loci on the $\mathrm{Z}$ chromosome, as females are hemizygous ( $\mathrm{ZW}$ ) and males are $\mathrm{ZZ}$ in birds. RAD loci with a female to male average depth ratio between 0.4 and 0.65 were then checked for alignment to the $\mathrm{Z}$ chromosome of the killdeer genome (Zhou et al. 2014) using our BLASTN results. RAD loci with both read depth and alignment support for Z-linkage were assigned to the $\mathrm{Z}$ chromosome dataset. $\mathrm{RAD}$ loci that were only "Z-linked" by one of the two methods, were removed from all datasets. RAD loci only present in females (i.e., indicative of being located on the $\mathrm{W}$ chromosome) were excluded by the above filter (i.e., missing data in five

Table 1 Genetic diversity of snowy plover (Charadrius nivosus) populations using four genetic marker datasets: autosomal and Z-linked ddRAD loci, microsatellites, and mtDNA. Shaded cells indicate populations/demes with genetic data for all four markers

\begin{tabular}{|c|c|c|c|c|c|c|c|c|c|c|c|c|c|c|c|c|c|c|c|c|}
\hline \multirow[b]{2}{*}{ Deme } & \multirow[b]{2}{*}{$\begin{array}{l}\text { Sampling site } \\
\text { (pop label) }\end{array}$} & \multirow[b]{2}{*}{ Lat } & \multirow[b]{2}{*}{ Long } & \multicolumn{4}{|c|}{ mtDNA (D-loop) $\dagger$} & \multicolumn{5}{|c|}{ Autosomal microsatellites } & \multicolumn{4}{|c|}{ ddRAD autosomal loci } & \multicolumn{4}{|c|}{ ddRAD Z-linked $^{\mathrm{b}}$ loci } \\
\hline & & & & $N$ & $N_{p o l y}$ & $h$ & $\theta$ & $N$ & $N_{p o l y}$ & $r$ & $\mathbf{H}_{e}$ & $F_{\mathrm{IS}}$ & $N$ & $N_{p o l y}$ & $\theta$ & $F_{\mathrm{IS}}$ & $N$ & $N_{p o l y}$ & $\theta$ & $F_{\text {IS }}$ \\
\hline \multirow{7}{*}{$\begin{array}{l}\text { western } \\
\text { nivosus }\end{array}$} & $\begin{array}{l}\text { UTA, CEU, MT } \\
\text { (combined) }\end{array}$ & - & - & 46 & 6 & $\begin{array}{c}0.61 \\
(0.05)\end{array}$ & 0.0063 & 50 & 14 & $\begin{array}{c}2.8 \\
(1.3)\end{array}$ & $\begin{array}{c}0.41 \\
(0.25)\end{array}$ & $\begin{array}{c}0.01 \\
(0.12)\end{array}$ & $\begin{array}{l}1 \\
8\end{array}$ & 870 & 0.0008 & $\begin{array}{l}-0.007 \\
(0.21)\end{array}$ & 8 & 34 & 0.0005 & $\begin{array}{c}-0.01 \\
(0.35)\end{array}$ \\
\hline & \multirow{5}{*}{$\begin{array}{l}\text { Utah, USA } \\
\text { (UTA) } \\
\text { Monterey bay, } \\
\text { USA (MT) } \\
\text { Ceuta, Mexico } \\
\text { (CEU) } \\
\text { Nayarit, Mexico } \\
\text { (NAY) } \\
\text { Texcoco, } \\
\text { Mexico (TEX) }\end{array}$} & 41.09 & -112.13 & 32 & 5 & $\begin{array}{c}0.65 \\
(0.01)\end{array}$ & 0.0023 & 25 & 13 & $\begin{array}{c}2.5 \\
(1.2)\end{array}$ & $\begin{array}{c}0.37 \\
(0.27)\end{array}$ & $\begin{array}{c}0.01 \\
(0.16)\end{array}$ & 8 & 601 & 0.0008 & $\begin{array}{l}-0.044 \\
(0.29)\end{array}$ & 3 & 22 & 0.0004 & $\begin{array}{l}-0.173 \\
(0.42)\end{array}$ \\
\hline & & 36.74 & -121.80 & 4 & 1 & $\begin{array}{c}0.50 \\
(0.07)\end{array}$ & 0.0013 & 0 & - & - & - & - & 1 & - & - & - & 1 & - & - & - \\
\hline & & 23.90 & -106.95 & 10 & 1 & $\begin{array}{l}0.48 \\
(0.02)\end{array}$ & 0.0008 & 25 & 12 & $\begin{array}{c}2.5 \\
(1.1)\end{array}$ & $\begin{array}{c}0.39 \\
(0.26)\end{array}$ & $\begin{array}{l}-0.02 \\
(0.24)\end{array}$ & 9 & 733 & 0.0008 & $\begin{array}{l}-0.003 \\
(0.28)\end{array}$ & 4 & 28 & 0.0005 & $\begin{array}{l}-0.055 \\
(0.44)\end{array}$ \\
\hline & & 22.43 & -105.59 & 0 & - & - & - & 8 & 11 & $\begin{array}{c}2.4 \\
(1.1)\end{array}$ & $\begin{array}{c}0.33 \\
(0.26)\end{array}$ & $\begin{array}{l}-0.01 \\
(0.27)\end{array}$ & 0 & - & - & - & - & - & - & - \\
\hline & & 19.54 & -99.00 & 0 & - & - & - & 23 & 12 & $\begin{array}{c}2.3 \\
(1.1)\end{array}$ & $\begin{array}{c}0.35 \\
(0.26)\end{array}$ & $\begin{array}{c}0.04 \\
(0.17)\end{array}$ & 0 & - & - & - & - & - & - & - \\
\hline & $\begin{array}{l}\text { San Quintin, } \\
\text { Mexico (SAQ) }\end{array}$ & 30.39 & -115.88 & 0 & - & - & - & 22 & 12 & $\begin{array}{c}2.4 \\
(1.2)\end{array}$ & $\begin{array}{c}0.36 \\
(0.27)\end{array}$ & $\begin{array}{c}0.02 \\
(0.14)\end{array}$ & 0 & - & - & - & - & - & - & - \\
\hline $\begin{array}{l}\text { eastern } \\
\text { nivosus }\end{array}$ & $\begin{array}{l}\text { Florida, USA } \\
\text { (FLO) }\end{array}$ & 30.29 & -86.73 & 29 & 2 & $\begin{array}{c}0.43 \\
(0.10)\end{array}$ & 0.0012 & 43 & 12 & $\begin{array}{c}2.2 \\
(0.8)\end{array}$ & $\begin{array}{c}0.41 \\
(0.17)\end{array}$ & $\begin{array}{c}0.08 \\
(0.12)\end{array}$ & $\begin{array}{l}1 \\
0\end{array}$ & 653 & 0.0007 & $\begin{array}{l}0.017 \\
(0.28)\end{array}$ & 6 & 26 & 0.0004 & $\begin{array}{l}0.003 \\
(0.43)\end{array}$ \\
\hline tenuirostris & $\begin{array}{l}\text { Cabo Rojo, } \\
\text { Puerto Rico } \\
\text { (CAR) }\end{array}$ & 17.97 & -67.19 & 23 & 7 & $\begin{array}{c}0.67 \\
(0.10)\end{array}$ & 0.0048 & 13 & 10 & $\begin{array}{c}1.8 \\
(0.8)\end{array}$ & $\begin{array}{c}0.42 \\
(0.17)\end{array}$ & $\begin{array}{l}-0.13 \\
(0.18)\end{array}$ & 9 & 403 & 0.0005 & $\begin{array}{l}-0.025 \\
(0.31)\end{array}$ & 4 & 5 & 0.0001 & $\begin{array}{l}-0.38 \\
(0.38)\end{array}$ \\
\hline occidentalis & $\begin{array}{l}\text { Paracas, Peru } \\
\text { (PAR) }\end{array}$ & -13.86 & -76.27 & 22 & 4 & $\begin{array}{l}0.40 \\
(0.12) \\
\end{array}$ & 0.0019 & 18 & 11 & $\begin{array}{l}2.2 \\
(0.7)\end{array}$ & $\begin{array}{l}0.40 \\
(0.19) \\
\end{array}$ & $\begin{array}{r}-0.012 \\
(0.20) \\
\end{array}$ & $\begin{array}{l}1 \\
0 \\
\end{array}$ & 379 & 0.0005 & $\begin{array}{c}-0.002 \\
(0.28) \\
\end{array}$ & 6 & 16 & 0.0003 & $\begin{array}{l}-0.128 \\
(0.33) \\
\end{array}$ \\
\hline
\end{tabular}

${ }^{a} \mathrm{mtDNA}$ diversity statistics by lineage are presented in the Table $\mathrm{S} 2$

${ }^{\mathrm{b}}$ Males only

$N=$ number of samples; $r=$ allelic richness; $N_{\text {poly }}=$ number of polymorphic loci; $h=$ haplotype diversity; $\theta=$ per site Watterson's theta; $H_{e}=$ expected heterozygosity; $F_{\mathrm{IS}}=$ inbreeding coefficient. Standard deviations are presented in brackets 
or more samples). We assigned all other clusters/loci to an "autosomal dataset."

\section{SNP filtering}

For SNP based analyses we retained one randomly selected biallelic SNP per RAD locus to minimise linkage. Finally, to reduce potential biases in Bayesian clustering solutions (Linck and Battey 2017), singleton SNPs were excluded from population structure analyses. For all other analyses, we included singleton SNPs. For diversity, correlation tests between geographic and genetic distances, and PCA analyses of the Z-linked SNP dataset we included only (diploid) males, whereas all other analysis included all individuals.

\section{Genetic diversity and differentiation}

For mtDNA we used DNAsp v6 (Librado and Rozas 2009) to calculate haplotype diversity. We calculated microsatellite allelic richness in MSA v4.05 (Dieringer and Schlötterer 2003) and expected heterozygosity in Arlequin v3.5 (Excoffier and Lischer 2010). For microsatellite and SNP datasets we used the adegenet package (Jombart 2008) in $R$ to calculate inbreeding coefficient $\left(F_{\text {IS }}\right)$ and the PopGenome (Pfeifer et al. 2014) package to calculate per site Watterson's theta $\left(\theta_{\mathrm{W}}\right)$. Where referred to, we used $R$ statistical software v3.6.0 (R Development Core Team 2019).

We calculated pairwise $F_{\mathrm{ST}}$ estimates between demes (nuclear genetic clusters identified with Structure Fig. 2) for autosomal SNPs, Z chromosome SNPs, microsatellites and mtDNA datasets in Arlequin. We calculated diversity statistics separately for all sampling sites, demes, and genetic lineages.

\section{Population structure}

For the mtDNA D-loop sequences, we constructed a haplotype network using the Templeton, Crandall and Sing (TCS, Templeton et al. 1992) method implemented in PopArt (Leigh and Bryant 2015) to visually inspect the distribution of haplotypes across demes and genetic lineages.

To determine genetic structure with SNPs and microsatellites we performed Bayesian cluster analysis using the program Structure v2.3.4 (Pritchard et al. 2000) automated for command line usage with StrAuto (Chhatre and Emerson 2017). We tested $K$ values between one and five for 1 million repetitions following a burn-in of 250,000 repetitions with 20 replicates for each $K$ value using an admixture model. Due to an a priori expectation of limited population differentiation, we additionally ran the program with the LOCPRIOR model (Hubisz et al. 2009). We merged runs for each $K$ value using Clumpak (Kopelman et al. 2015) implemented through Pophelper (Francis 2017). We determined the most biologically relevant $K$ value by inspecting Delta $\mathrm{K}$ values (Evanno et al. 2005), $\operatorname{Ln} \operatorname{Pr}(X \mid K)$ values, as recommended by Janes et al. (2017), and the bar plots of ancestry proportions grouped according to geographic distance between sampling sites and populations.

As an alternative approach to visualizing population structure, we also ran a principal components analysis (PCA) based on the same set of SNPs used in the Structure analysis. Following the approach of Novembre and Stephens (2008), we scored each genotype as having 0,1 or 2 copies of the reference allele. In the case of missing data $(\sim 1.5 \%$ of the data), individuals were assigned a value equal to two times the global frequency of the alternative allele at that SNP. In the case of Z-linked SNPs, females were scored as having 0 or 1 copies of the reference allele and one allele missing, such that input genotypes for females were calculated as 0 or 1 plus the global frequency of the alternative allele at each SNP. PCAs were computed in $R$ using the function prcomp.

Finally, we analysed the full set of variable autosomal loci in fineRADstructure (Malinsky et al. 2018), which leverages the information available in the linkage of SNPs within each RAD locus to infer patterns of recent shared ancestry. More specifically, each individual's ancestry at a given locus is allocated to other individuals that carry either an identical haplotype (or most closely related haplotype if the focal individual has a unique allele). Rare haplotypes, which are on average of more recent origin (Kimura and Ohta 1973), make the greatest contribution to the resulting pairwise coancestry coefficients. Thus, the fineRADstructure analysis uses all of the variable sites at each locus and focuses on a different kind of information in the data than does Structure or PCA.

\section{Correlation between geographic and genetic distances}

To test for a correlation between geographic and genetic distances we used Mantel tests with 9999 permutations in the $R$ package adegenet (Jombart 2008). For mtDNA sequences, we calculated genetic distances using the Maximum Composite Likelihood method implemented in MEGAx (Tamura et al. 2004; Kumar et al. 2018). We calculated individual pairwise genetic distances from microsatellites and SNPs as 1 - kinship coefficient (Loiselle et al. 1995) estimated using SPAGeDi v1.5 (Hardy and Vekemans 2002). We then created Euclidean distance matrices for geographic distances using GenALEx 6.501 (Peakall and Smouse 2012). We performed these analyses across all populations and separately within nivosus, which was sampled at multiple breeding sites (Fig. 1). 


\section{Autosomal SNPs $(n=1089) \quad$ Autosomal microsatellites $(n=15) \quad$ Z-linked SNPs $(n=52)$}
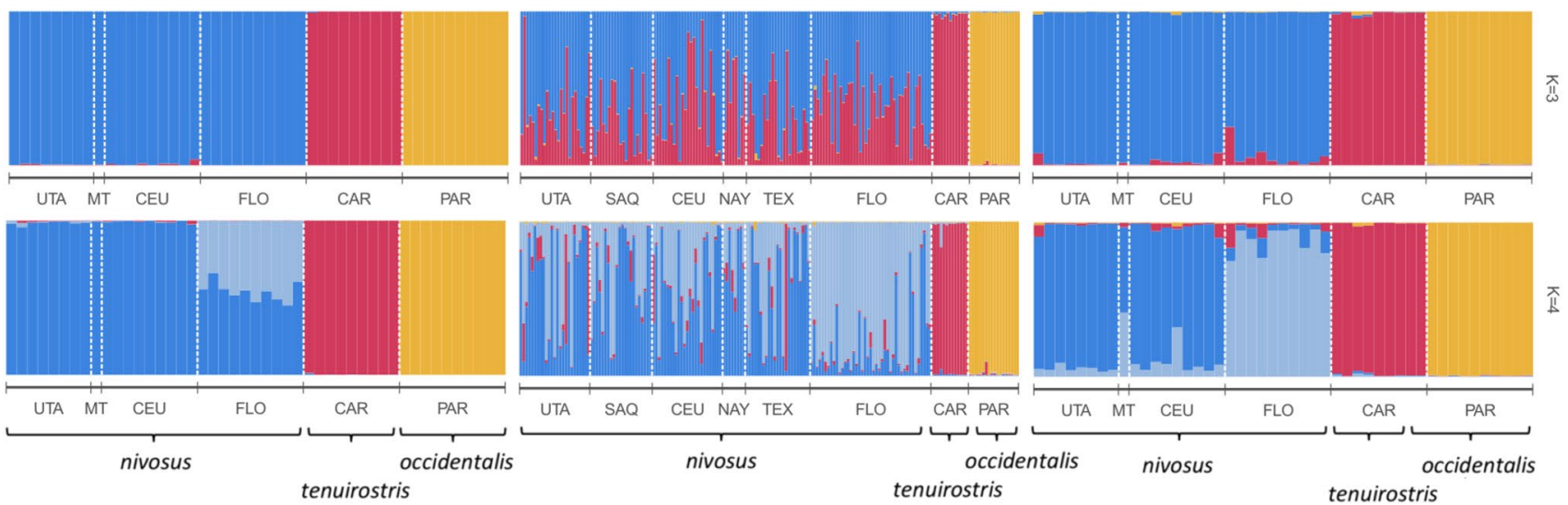

Fig. 2 Results of Bayesian clustering analyses of snowy plovers using three genetic datasets (1089 autosomal SNPs; 15 autosomal microsatellites and $52 \mathrm{Z}$-linked SNPs) estimated by Structure. The most likely models $(K=3$ and $K=4)$ are shown. See Table 1 for population

\section{Demography}

We used the microsatellite dataset to investigate past effective population size $\left(N_{\mathrm{e}}\right)$ changes using Bottleneck v1.2.02 (Piry et al. 1999) and Msvar v1.3 (Beaumont 1999; Storz and Beaumont 2002). Bottleneck tests for heterozygosity excess from the observed number of alleles under the assumption that after a recent bottleneck there is higher heterozygosity under Hardy-Weinberg equilibrium than under a mutation drift model (Cornuet and Luikart 1996). We used the Wilcoxon signed-rank test implemented in Bottleneck with a two-phase mutation model to assess the significance of the excess. Using Msvar we inferred the demographic history of each deme (western nivosus, eastern nivosus, tenuirostris and occidentalis) by comparing three models: bottleneck, expansion and stable population size based on the full likelihood, coalescent simulation method implemented in the software. Populations within western nivosus were also tested independently because of the controversial status of the Pacific coast population segment, but these analyses produced nearly indistinguishable results (Fig. S1). Therefore, we combined these populations to provide deme-wide estimates. The stable population model assumed the same $N_{\mathrm{e}}$ values for $N_{0}$ (current) and $N_{1}$ (ancestral). For the bottleneck, we specified the priors for $N_{1}$ to be wider than at $N_{0}$ (bottleneck), whereas, we assumed the opposite (priors for $N_{0}$ wider than $N_{1}$ ) for the expansion model. We set the microsatellite mutation rate $(\mu)$ to $5 \times 10^{-4}$ substitutions per site per generation (Peery et al. 2012), with a range of $10^{-3}$ to $10^{-5}$. We ran each model with $1 \times 10^{10} \mathrm{MCMC}$ iterations, thinning every 100,000 steps to end with 100,000 thinned updates. The initial $20 \%$ were discarded as burn-in. We performed multiple runs with broad priors (Table S3) codes and respective genetic lineages are indicated below plots. Eastern nivosus are represented by population FLO and western nivosus by populations UTA, MT, CEU, SAQ, NAY and TEX

to influence posterior distributions as little as possible. We assessed convergence of the MCMC simulations for each model with the Gelman and Rubin's diagnostic (Gelman and Rubin 1992; Brooks and Gelman 1998) calculated using the Boa package v1.1.7 (Smith 2007) in $R$.

To examine population demography with the autosomal SNPs we applied Approximate Bayesian Computation (ABC, Beaumont et al. 2002) in ABCtoolbox v2 (Wegmann et al. 2010) to compare our empirical data to simulated results from three different demographic models (stable, bottleneck and expansion). ABC was conducted for single demes independently: western nivosus (California (USA), Utah (USA) and Ceuta (Mexico) combined), eastern nivosus (Florida (USA)), occidentalis (Peru) and tenuirostris (Puerto Rico).

$\mathrm{ABC}$ uses the following logic (reviewed by Beaumont 2010). First, summary statistics are calculated from the empirical dataset in addition to a set of simulated datasets created based on pre-defined demographic models (involving, for example, population divergence, bottlenecks, expansions, migration). Second, summary statistics from the empirical dataset are compared with those from the simulated datasets to reveal the best fitting demographic model. Finally, differences between the empirical and best fitting model are used to predict the posterior distributions of model parameters (e.g. past/current effective population size and time of divergence; Beaumont et al. 2002).

We specified wide priors (Table S4) with uniform distributions, and modelled effective population sizes with $\log _{10}$ transformed values. Our dataset contained 1288 individual independent autosomal SNPs (see "Results": SNP filtering). To simulate 1 million datasets for model optimisation we used fastsimcoal v2.6 (Excoffier and Foll 2011; Excoffier 
et al. 2013). We computed summary statistics (total heterozygosity, mean and standard deviation (SD) for the heterozygosity over SNP loci, number of alleles over all SNP loci, mean and s.d. for the number of alleles over SNP loci) for each dataset (simulated and observed SNPs) with the console version of Arlequin v3.5, arlsumstat (Excoffier and Lischer 2010).

To infer the demographic model providing the best fit to our observed data we calculated the Euclidean distance between observed and simulated datasets, and carried forward the closest 5000 simulations for model fitting and posterior estimations. For each model we used the general linear post-sampling adjustment step within ABCtoolbox to calculate posterior probabilities and marginal densities. We evaluated the best fitting demographic scenario by pairwise comparisons of the marginal densities and $p$ values of each model (Wegmann et al. 2010). Spearman's Rho statistics to assess pairwise correlation between summary statistics were calculated, and highly correlated statistics were removed before model comparisons. The uncorrelated summary statistics used in model comparisons were the total number of alleles over loci and the mean heterozygosity. We considered models with $p$-values greater than 0.05 as possible and the best fitting demographic scenario was required to have a Bayes Factor $(B F) \geq 3$. We tested for stable, expansion, or bottleneck models within the last 1000 years as this focused our analysis on the period of intensive human induced change to coastal habitats (Lotze et al. 2006; Spatz et al. 2017). The generation time for ABCtoolbox and Msvar was set to one year based on monitoring data from natural populations (e.g. Eberhart-Phillips et al. 2017).

In addition, we generated recent migration estimates between demes using the 1288 autosomal SNP dataset with a modified version of BayesAss v3 (Wilson and Rannala 2003; available from https://github.com/smussmann82/ BayesAss3-SNPs), which allows the analysis of large SNP datasets. To optimise acceptance rates, we first explored migration mixing parameter combinations (migration rates $m$ ranging from 0.1 to 0.6 , allele frequencies $a$ ranging from 0.1 to 0.6 ; inbreeding coefficients $f$ ranging from 0.1 to 0.5 ) with short default numbers of MCMC steps, burn-in, and sampling values as recommended by Rannala (2015). Once the acceptance rates fell between 20 and 60\% (Rannala 2015) we conducted three longer runs with different seeds, with the following parameter combination: $m=0.4, a=0.6$, $f=0.4$, for 10 million MCMC steps, 1 million burn-in and sampling every 500 iterations. We visualised the results and determined the convergence of the three runs using TRACER v1.7 (Rambaut et al. 2018) and averaged the results of the runs to provide migration rate estimates.

\section{Results}

\section{SNP generation with ddRAD}

We obtained a total of 62.5 million sequence reads from 47 individuals. After initial filtering and de-multiplexing, read coverage ranged from 0.46 to 1.4 million reads per individual with a mean $( \pm S D)$ of $1.1( \pm 0.15)$ million reads. From these we identified 23,026 putative RAD loci, including 4859 loci that passed quality filters (4582 putative autosomal and 277 putative Z-linked). Of these, 1338 autosomal and 65 Z-linked RAD loci included between 1-4 SNPs and/or indels. Selection of one biallelic SNP per locus resulted in datasets comprising 1288 autosomal, and $65 \mathrm{Z}$-linked SNPs. Excluding singletons (for Structure runs and PCA), the dataset were reduced to 1089 autosomal SNPs and 52 Z-linked SNPs.

\section{Genetic diversity}

Overall, we identified 25 unique haplotypes for a $424 \mathrm{bp}$ section of the mtDNA control region (D-loop). MtDNA haplotype diversity was highest in occidentalis, followed by nivosus (eastern and western combined), and tenuirostris (Table 1). Microsatellite mean allelic richness was low and ranged from 1.8 in tenuirostris up to 2.5 in western nivosus populations (Utah and Ceuta; Table 1). Similarly, per site genetic diversity (Watterson's theta) across all quality filtered autosomal RAD loci ( $n=4582$ loci) was low overall but highest in nivosus (eastern and western combined, 0.0008 ), followed by tenuirostris (0.00048) and occidentalis (0.00045) (Table 1). The highest diversity of Z-linked loci was found in nivosus (eastern and western combined), followed by occidentalis and lastly tenuirostris (Table 1). No substantial level of inbreeding was detected, however, comparing between populations, eastern nivosus consistently had the greatest mean inbreeding coefficient ranging from 0.02 $( \pm 0.32)$ based on autosomal SNPs to $0.08( \pm 0.12)$ based on microsatellites (Table 1).

\section{Population structure}

\section{mtDNA}

Based on mtDNA haplotype data, the three genetic lineages were not strictly distinct. We observed multiple shared haplotypes between nivosus and tenuirostris, whereas, only one haplotype was shared between occidentalis and tenuirostris (Fig. 3). On the other hand, haplotypes from occidentalis and tenuirostris appear to be more closely related (Fig. 3). Eastern nivosus had one exclusive haplotype, whereas, we 
detected twelve exclusive haplotypes in western nivosus, three in occidentalis, and four in tenuirostris (Fig. 3).

\section{Microsatellites and SNPs}

The Bayesian structure analysis conducted with SNP and microsatellite datasets all split occidentalis from the remaining two genetic lineages at $K=2$ (data not shown). At $K=3$, the SNP datasets, but not the microsatellite dataset, suggest three distinct clusters that are consistent with the updated delineation of the three subspecies proposed by Funk et al. (2007) (Fig. 2). Without location prior information, the microsatellite dataset showed high levels of estimated admixture between tenuirostris the nivosus at $K=3$ (Fig. 2). However, with location prior information the three genetic lineages could be clearly discriminated with microsatellites (Fig. S2). At $K=4$, Structure analysis further split the nivosus lineage into eastern nivosus (Florida) and western nivosus (all other nivosus sampling sites) for both SNP datasets (Fig. 2). Furthermore, the autosomal SNP dataset showed minimal apparent admixture between tenuirostris and eastern nivosus. Increasing $K$ to 5 did not result in further meaningful clustering consistent with geographic information. The eastern and western nivosus distinction was most pronounced with Z-linked SNPs compared to autosomal SNPs, and the microsatellite dataset only showed weak distinction between eastern and western nivosus (Fig. 2) but improved when location information was added as a prior (Fig. S2).

The three genetic lineages were separated in the PCAs using autosomal and Z-linked SNPs (Fig. S3). Separation of eastern and western nivosus became clear when plotting PC1 against PC3 (Fig. S3B). Fine scale structuring was less pronounced within Z-linked SNP dataset (Fig. S3C).
The co-ancestry matrix of individuals using the autosomal RAD loci further supported the clear distinction of the three genetic lineages and additional sub-structuring within nivosus to recover eastern and western demes (Fig. 4). Occidentalis was consistently the most distinct lineage from Structure, PCA (Fig. S3), and fineRADstructure (Fig. 4) analyses compared to tenuirostris and nivosus.

\section{Pairwise differentiation}

Between genetic lineages we found high and significant pairwise population differentiation with all markers (Table 2). The occidentalis lineage was most differentiated from all other demes/lineages (Table 2). Pairwise differentiation between eastern and western nivosus demes showed significant differentiation $\left(F_{\mathrm{ST}}=0.04-0.11\right)$ in microsatellites as well as autosomal and Z-linked SNPs, but not in mtDNA $\left(\Phi_{\mathrm{ST}}=0.03\right)$.

\section{Correlation between geographic and genetic distances}

We found significant correlation between geographic and genetic distances for autosomal and $\mathrm{Z}$ chromosome datasets across all lineages and within nivosus individuals only (all lineages/nivosus only: autosomal SNPs $r$ (mantel test statistic $)=0.70 / 0.61, \mathrm{Z}$ chromosome SNPs $r=0.75 / 0.45$, microsatellites $r=0.38 / 0.11$, all $p<0.05$; Fig. 5). For mtDNA, the correlation between geographic and genetic distances was only significant for the dataset that included all genetic lineages (all lineages $r=0.52, p<0.05$, Fig. 5a; nivosus only $r=-0.02, p=0.73$, Fig. 5b). For nuclear markers, the correlation between geographic and genetic distances was weakest for microsatellites and
Fig. 3 Haplotype network of snowy plover D-loop mtDNA sequences constructed using the statistical parsimony method $(T C S)$. Samples were collected from localities representing all previously identified genetic lineages. Colour coding follows Fig. 1

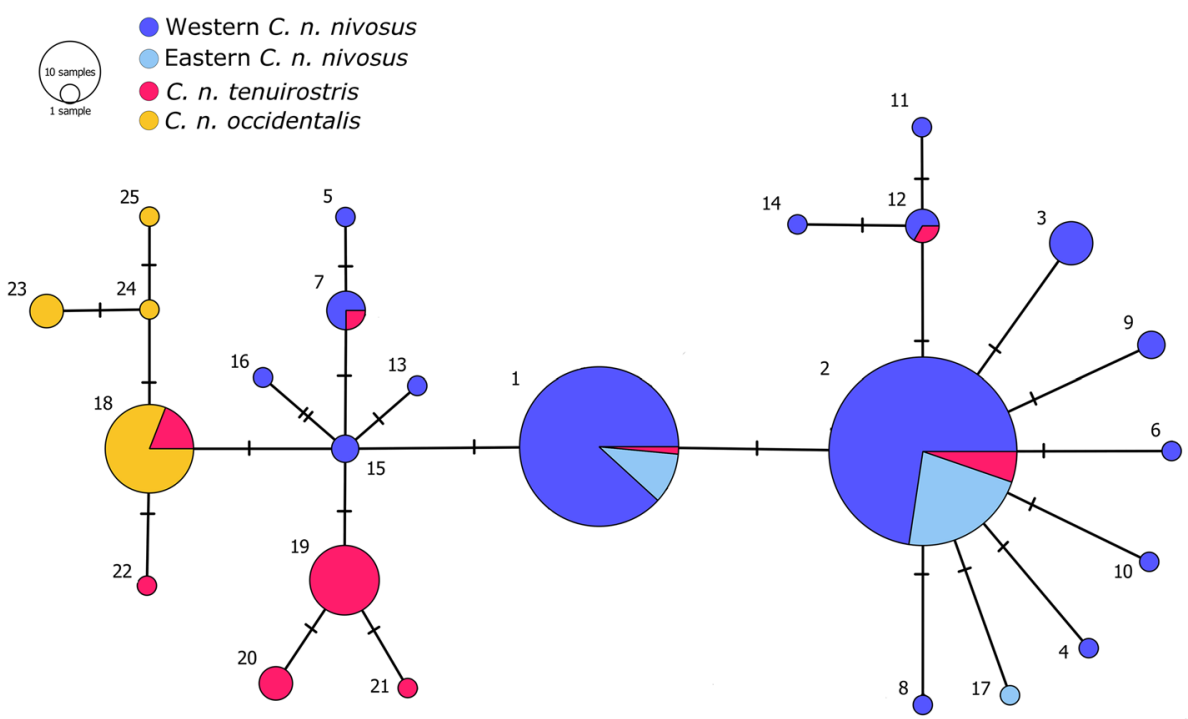


strongest for $\mathrm{Z}$ chromosome SNPs across all subspecies (Fig. 5a). Within nivosus only, we detected the strongest correlation between geographic and genetic distances with autosomal SNPs, followed by $\mathrm{Z}$ chromosome SNPs, and a weak but significant correlation with microsatellites (Fig. 5b).

\section{Demography}

Overall our demographic analyses provided strong evidence for population bottlenecks in all genetic lineages during the past 1000 years. Specifically, Msvar predicted bottlenecks occurring between 56 and 445 years ago (YA) when the effective population size decreased from an average of 5983 $( \pm 581)$ to $33( \pm 19)$ (Table 3$)$. We found the largest effective population decline in western nivosus and tenuirostris and the least decline in occidentalis (Fig. 6 and Table 3; Table S5). According to the $\mathrm{ABC}$ analysis, the population bottleneck model fitted our autosomal SNP datasets best for eastern nivosus, tenuirostris and occidentalis with Bayes Factors of $>5$. However, none of the three tested scenarios received sufficient support in western nivosus (Table S6). ABC estimated that the bottlenecks occurred most recently in tenuirostris and occidentalis (221 YA and 302 YA respectively) than in eastern nivosus (784 YA) (Table 3). Posterior and prior distributions of the ABCtoolbox bottleneck scenario are presented in Supplementary Material (Fig. S4). Only tenuirostris showed statistical support for a bottleneck based on heterozygosity excess with the program Bottleneck (Wilcoxon test: $p=0.04$ ).

We found low but significant levels of recent migration ( $m=0.02-0.03$ ) between lineages in the BayesAss analyses (Table S7). Among demes, there was one notable exception of high migration ( $m=0.26$, s.d. 0.04$)$ indicating gene flow from western to eastern nivosus. However, given the low sample sizes and the weak population differentiation between eastern and western nivosus $F_{\mathrm{ST}} \sim 0.05$, these results should be interpreted with caution (Meirmans 2014).

\section{Discussion}

Examining population structure based on a comprehensive assessment that included four types of genetic data, we find genetic support for the three genetic lineages delineated previously as subspecies (Funk et al. 2007). These genetic lineages largely correspond to the proposed geographic ranges of the subspecies: nivosus (Mexico and USA), tenuirostris (Bermuda and Caribbean), and occidentalis (South America). The level of genetic divergence among the snowy plover genetic lineages/demes in microsatellite $\left(F_{\mathrm{ST}}=0.04-0.47\right)$, autosomal SNPs $\left(F_{\mathrm{ST}}=0.05-0.58\right)$, Z-linked SNPs $\left(F_{\mathrm{ST}}=0.12-0.71\right)$ and mtDNA data $\left(\Phi_{\mathrm{ST}}=0.03-0.79\right)$ is similar to that observed among other plover subspecies, such

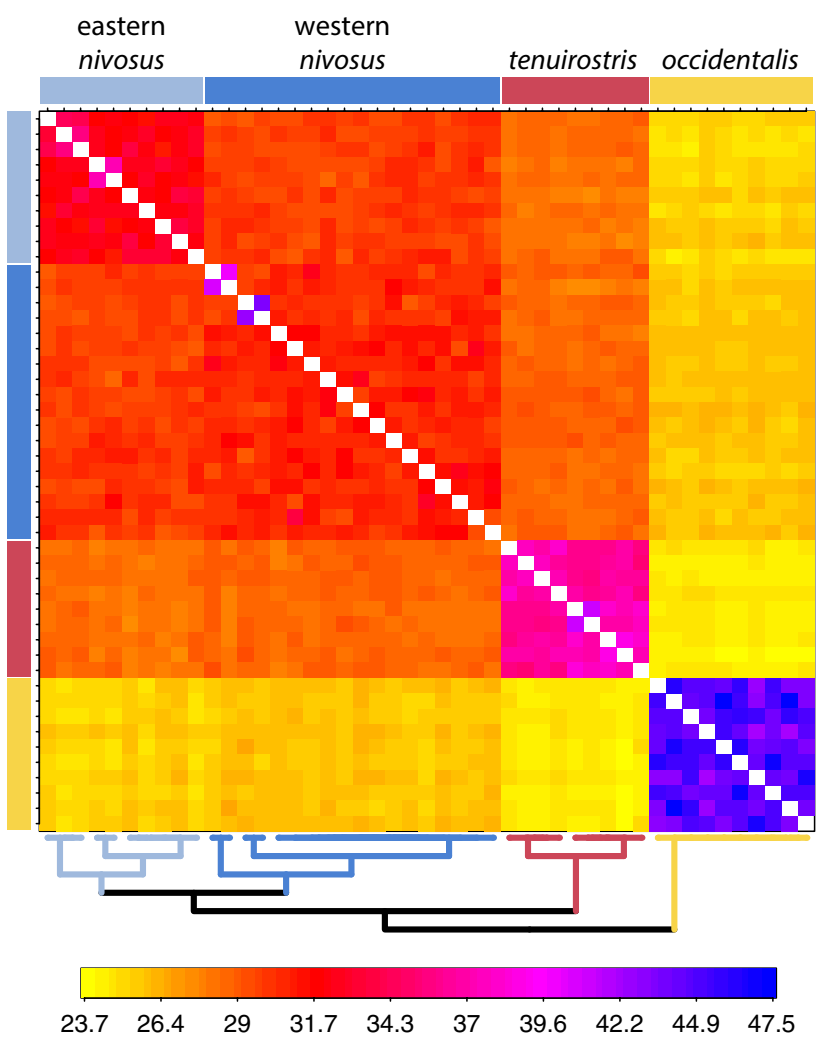

Fig. 4 Pairwise co-ancestry matrix and dendrogram from fineRADstructure analysis of snowy plover demes. The co-ancestry coefficients, ranging from low (yellow) to high (blue), provide a relative index of recent shared ancestry between the focal individual (along the vertical axis) and other all other individuals in the analysis (along the horizontal axis). The co-ancestry matrix was created from 1338 autosomal RAD loci

as the piping plover (Charadrius melodus, Miller et al. 2010) and the chestnut banded plover (Charadrius pallidus dos Remedios et al. 2017). Genetically, the three snowy plover lineages are more differentiated than the subspecies of some other shorebirds such as dunlin, Calidris alpina, Miller et al. 2015) or redshank, Tringa tetanus, Ottvall et al. 2005). The differences at microsatellites and mtDNA are also more pronounced than between white-faced plover (Charadrius alexandrinus dealbatus) and Kentish plover (Charadrius alexandrinus), $F_{\mathrm{ST}}=0.01$, Rheindt et al. 2011). The latter two taxa are considered separate species by some authorities based on phenotypic differences (del Hoyo et al. 2018; but see Clements et al. 2018; Gill and Donsker 2018) and recent analyses have described further genomic differences between both taxa (Sadanandan et al. 2019; Wang et al. 2019). We found that occidentalis is the most distinct lineage of snowy plovers with consistently the greatest level of differentiation across all analyses. We suggest the uniqueness of this lineage should be considered when prioritising conservation efforts for South American shorebirds. 
Table 2 Pairwise $F_{\mathrm{ST}}$ (and $\Phi_{\mathrm{ST}} \mathrm{mtDNA}$ ) comparisons between demes of snowy plover (Charadrius nivosus), see Fig. 2 for population clustering

\begin{tabular}{c|cccccc}
\multicolumn{2}{c}{} & \multicolumn{2}{c}{$\begin{array}{c}\text { western } \\
\text { nivosus }\end{array}$} & $\begin{array}{c}\text { eastern } \\
\text { nivosus }\end{array}$ & tenuirostris & occidentalis \\
\hline $\begin{array}{c}\text { western } \\
\text { nivosus }\end{array}$ & & & & & & \\
eastern & & & & & & \\
nivosus & 0.04 & 0.03 & & & & \\
& 0.12 & 0.05 & & & & \\
tenuirostris & 0.12 & 0.54 & 0.15 & 0.47 & & \\
& 0.31 & 0.22 & 0.28 & 0.28 & & \\
occidentalis & 0.43 & 0.71 & 0.47 & 0.79 & 0.47 & 0.48 \\
& 0.48 & 0.38 & 0.53 & 0.45 & 0.71 & 0.58
\end{tabular}

Bold: significant; shaded only: microsatellites; shaded + italic: mtDNA; non-shaded only: Z-linked SNPs; non-shaded + italic: autosomal SNPs
By combining new data with those from two studies (Funk et al. 2007; D'Urban Jackson et al. 2017) we have substantially increased the number of genetic markers, individuals and sampling locations assessed. The SNP results corroborate previous findings (Funk et al. 2007) that tenuirostris lineage is distinct from nivosus and should be considered as a separate conservation unit. At the same time, individuals sampled from Florida (eastern nivosus) are more closely related to other nivosus populations, rather than the earlier delineation which grouped it with Caribbean tenuirostris (American Ornithologist's Union 1957). This finding supports the current state-wide protection of Florida snowy plovers as a separate management unit. Avian subspecies are defined by phenotypic differences between geographically distinct populations. So far, such differences between Caribbean tenuirostris and eastern nivosus have not been reported, preventing the delineation of a separate subspecies for either tenuirostris or eastern nivosus. The exact geographic ranges of the two nivosus demes (eastern and western) are currently unknown. Our study lacked samples from existing intermediate breeding populations such as Kansas, Texas, Alabama and Lousiana, which are needed to fully characterise the boundaries of eastern and western nivosus demes. Previously, the American Ornithologist's Union assigned all mainland snowy plovers east of Louisiana to tenuirostris and all western snowy plovers to nivosus. This delineation may serve as a useful primer for further work that aims to characterize the geographic ranges of the demes in detail. Our estimates of recent migration suggest that eastern snowy plover populations receive gene flow from western populations, whereas gene flow in the opposite direction is minimal. This directional bias maybe the result of wintering western migrants occasionally remaining to breed within the breeding distribution of the eastern snowy plover.

Snowy plovers have been the subject of several movement and demographic studies, though none so far have encompassed the entire range (Warriner et al. 1986; Stenzel et al. 1994, 2007, 2011; Eberhart-Phillips and Colwell 2014; Aiello-Lammens and Akcakaya 2016; Cruz-López et al. 2017; Eberhart-Phillips et al. 2017). Therefore, the long distance dispersal behaviour of this species remains poorly described and anecdotal. We currently lack sighting data to support or reject the genetic inference of unidirectional gene flow from western nivosus populations in Florida. Such gene flow from larger western to smaller eastern nivosus populations may provide a crucial bolstering effect against population declines in the more vulnerable eastern deme (Lamonte et al. 2002).

Despite the significant differentiation between the eastern and western nivosus demes, we observed only a weak correlation between geographic and genetic distances within the entire nivosus subspecies. At first, this appears surprising given the large distance between sampled sites $(>3000 \mathrm{~km})$. However, weak clinal structure or genetic homogeneity is common in shorebird populations, including Temminck's stint Calidris temminckii (Rönkä et al. 2012), ruff, Philomachus pugnax (Verkuil et al. 2012), mountain plover Charadrius montanus (Oyler-McCance et al. 2008) and the closely related Kentish plover, $C$. alexandrinus (Küpper et al. 2012). Interestingly, across the entire range of snowy plovers, we find that Z-linked markers show the strongest correlation between geographic and genetic distances compared to autosomal SNPs, microsatellites, and maternally inherited mtDNA. This result is consistent with male philopatry and female biased dispersal. Female biased dispersal is generally common across avian families regardless of mating system (Greenwood 1980; Clarke et al. 1997). Field observations suggest strong female biased dispersal in snowy plovers (Stenzel et al. 1994, 2007; Paton and Edwards 1996; Colwell et al. 2007; Pearson and Colwell 2014), a pattern that may be explained by the "dispersal-to-mate" hypothesis. The "dispersal-to-mate' hypothesis predicts 
Fig. 5 Pairwise individualbased correlation between geographic and genetic distances across snowy plover breeding populations (a) across all lineages, and (b) within $C$. n. nivosus only, assessed with four genetic datasets. Regression lines are provided where the correlation is significant $(\mathrm{p}<0.05)$
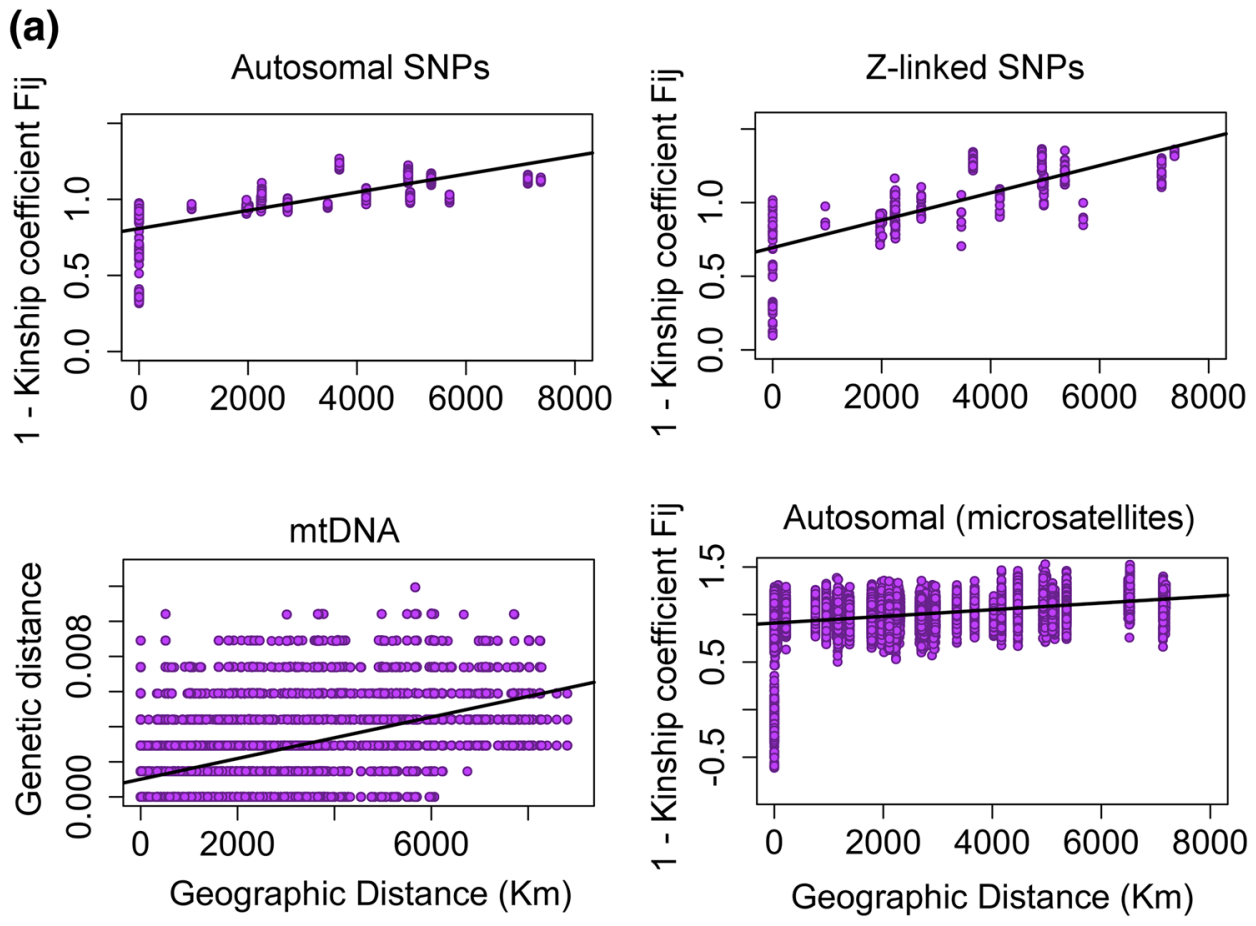

(b)
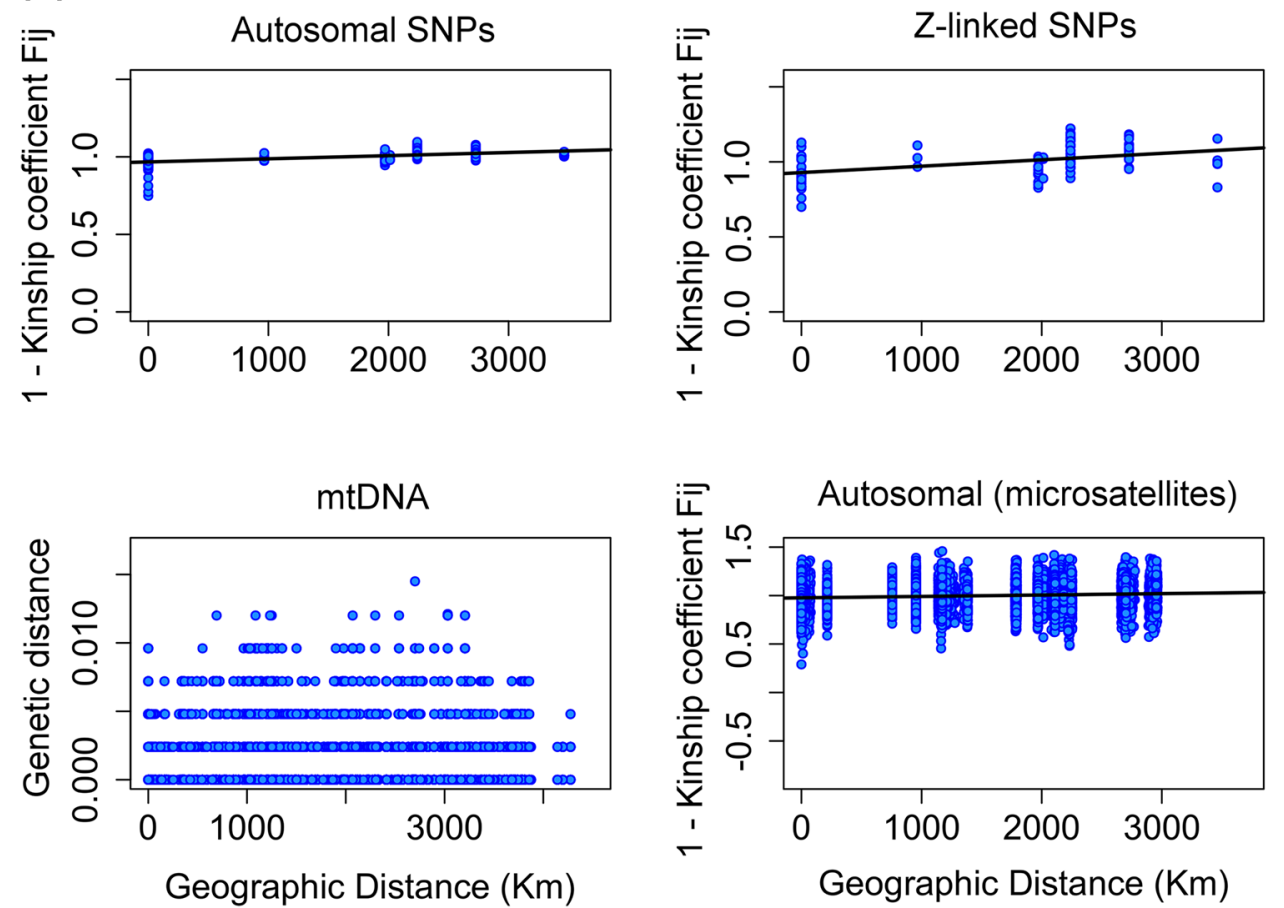

that polygamous females disperse to access more mates and consequently achieve higher breeding success (Küpper et al. 2012; D'Urban Jackson et al. 2017).

Autosomal polymorphic SNPs showed strong support for four conservation units in population structure analyses (Figs. 2, 4, S3). This highlights the advantages of using as many independent genetic markers as possible when investigating potentially controversial fine scale population structure, especially in high gene flow species such as the snowy plover (e.g. Ruegg et al. 2014; Vendrami et al. 2017). Differences in effective population size between mitochondrial, autosomal and sex-linked loci might also contribute to differences in level of genetic structure observed between genetic data sets. Assuming similar variance in male and 
Table 3 Effective population size $\left(N_{\mathrm{e}}\right)$ and time of bottleneck of snowy plover (Charadrius nivosus) demes estimated with Msvar and ABCtoolbox (shaded cells) with $95 \%$ highest posterior densities (HPD)

\begin{tabular}{|c|c|c|c|c|c|c|}
\hline & \multicolumn{2}{|c|}{ Current $N_{\mathrm{e}}$} & \multicolumn{2}{|c|}{ Ancestral $N_{\mathrm{e}}$} & \multicolumn{2}{|c|}{ Time of bottleneck } \\
\hline & Mode & HPD95\% & Mode & HPD95\% & Mode & HPD95\% \\
\hline \multirow{2}{*}{$\begin{array}{c}\text { C. } n . \\
\text { tenuirostris }\end{array}$} & 17 & $<1-423$ & 6,009 & 227 -inf. & 241 & $<1-10,916$ \\
\hline & 290 & $10-5,941$ & 17,397 & 330 -inf. & 221 & $26-935$ \\
\hline \multirow{2}{*}{$\begin{array}{c}\text { C. } n . \\
\text { occidentalis }\end{array}$} & 51 & $<1-985$ & 5,200 & 454 -inf. & 432 & $<1-12,149$ \\
\hline & 126 & $25-5,940$ & 5,231 & 152 -inf. & 302 & $61-970$ \\
\hline \multirow{2}{*}{$\begin{array}{l}\text { C. n. nivosus } \\
\text { (western) }\end{array}$} & 17 & $<1-576$ & 6,600 & 576 -inf. & 56 & $<1-2,148$ \\
\hline & - & - & - & - & - & - \\
\hline \multirow{2}{*}{$\begin{array}{l}\text { Cn. nivosus } \\
\text { (eastern) }\end{array}$} & 47 & $<1-1,455$ & 6,121 & 449 -inf. & 445 & $1-16,831$ \\
\hline & 59 & $10-5,941$ & 3,963 & 142 -inf. & 784 & $112-1,000$ \\
\hline
\end{tabular}

inf. over $10^{5}$ individuals, Msvar values are derived from the bottleneck scenario

female reproductive success, autosomal loci have the highest effective population size, followed by Z-linked loci and then mtDNA. Relatively high $\mathrm{Z}$ chromosome divergence is commonly observed in birds (Irwin 2018), which may be enhanced by "Fast-Z" evolution (Mank et al. 2007; Meisel and Connallon 2013) in addition to differences in effective population size. In snowy plovers, $\mathrm{Z}$ chromosome differentiation based on $F_{\mathrm{ST}}$ values was greater than for autosomal SNPs. The ability of a relatively small number of Z-linked SNPs to distinguish between eastern and western snowy plovers in Bayesian cluster analysis was higher than that of the autosomal SNPs, although the Z-linked SNP PCA indicated weak distinction between the two nivosus demes. Furthermore, Z-linked SNPs and autosomal SNPs produced similar correlations between geographic and genetic distances. The similarity of general spatial patterns produced by the two SNP datasets is striking given the difference in number of polymorphic markers (Z-linked: $n=52 / 65$ excluding/including singletons; autosomal: $n=1089 / 1288$ excluding/including singletons).

Consistent with previous findings (Funk et al. 2007), we find no evidence of genetic differentiation between coastal and interior western nivosus populations and no differentiation among coastal Pacific populations. This is not surprising given the high dispersal observed in this species (Stenzel et al. 1994). To detect putative fine scale differentiation within this deme, substantially greater sampling of the genome might be required, with the most fruitful approach being an analysis of whole genome sequences (WGS). Combining a WGS approach with improved sampling strategy to encompass the entire range of the species would enable not only the delineation of deme boundaries but also allow for an investigation of adaptive variation (Kjeldsen et al. 2016).

Also supporting previous studies, we found that the current effective population sizes of snowy plover subspecies and demes are low (Funk et al. 2007). Our demographic models suggest that this is most likely the result of strong population bottlenecks in all genetic lineages/demes that have occurred within the last 1000 years. As a result of these bottlenecks, the effective population sizes of the genetic lineages/demes have been reduced by at least $98 \%$. Overall there was remarkable similarity between the full likelihood (Msvar, microsatellites) and ABC (ABCtoolbox, autosomal SNPs) methods, with the exception of a lack of fit between any of the tested $\mathrm{ABC}$ demographic scenarios and data for
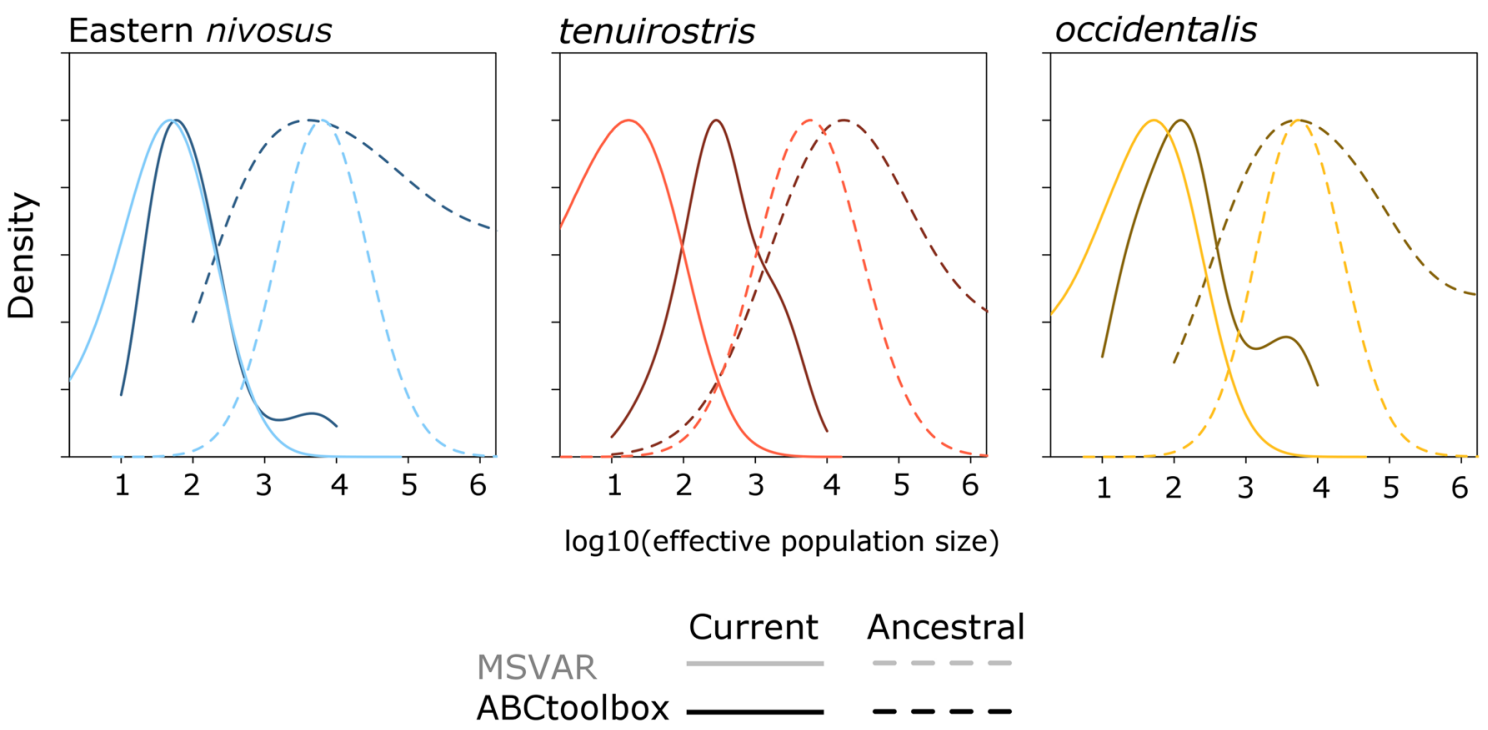

Fig. 6 Effective population size (current and ancestral) of Eastern nivosus, tenuirostris, and occidentalis snowy plover genetic lineages estimated by Msvar and ABCtoolbox. Density is normalised for comparison of the methods. ABCtoolbox posteriors are restricted by prior parameter values. Effective population size is reported on $\log _{10}$ scale. Western nivosus did not fit any of the modelled demographic scenarios tested with ABCtoolbox and is therefore not shown 
the western nivosus deme. This may have been caused by conflicting demographic trends across the vast breeding range. The western nivosus range spans large latitudinal and longitudinal gradients (more than 30 and 40 degrees, respectively), and encompasses populations that have likely experienced episodes of both growth and contraction. For example, western nivosus populations at the Pacific coast declined in the 1980s (Page et al. 1991) but due to intensive conservation effort they have stabilised or even increased over the last 20 years based on census results (Mullin et al. 2010; Colwell et al. 2017; Feucht et al. 2017). In contrast, Pacific populations in Mexico appear to be rapidly declining (Galindo-Espinosa and Palacios 2015; Cruz-López et al. 2017).

Both ABC and Msvar models inferred effective population sizes far smaller than the census sizes of breeding snowy plover populations (Thomas et al. 2012). For example, the census size of eastern snowy plovers has been estimated between 683 and 1022 (Thomas et al. 2012), whereas, our effective population size estimate was between 47 (Msvar) and 59 (ABC) albeit with wide confidence intervals (CI) of < 1-1455 (Msvar) and 10-5941 (ABC). Even more surprisingly, the western nivosus population size was estimated at 17 (Msvar, CI: < 1-576), whereas, the census size is over 8000 (Thomas et al. 2012). These discrepancies may either have technical or biological explanations. Shafer et al. (2015) found that a larger number of genetic markers/loci yielded more power in estimating the parameters of demographic models using $\mathrm{ABC}$, with over 50,000 loci being needed for accurate effective population size estimations. The accuracy of ABC compared to other methods in estimating effective population size is largely unknown (Wang et al. 2016), and ascertainment bias in SNP datasets can lead to erroneous temporal estimates (Quinto-Cortés et al. 2018). Furthermore, the large confidence intervals of all the estimated parameters should be considered when interpreting these results. Snowy plover reproductive behaviour and population ecology may further contribute to the discrepancy between effective and census population sizes and reduce genetic diversity. These populations are highly male-biased (Carmona-Isunza et al. 2017; Eberhart-Phillips et al. 2017), deviating from the basic model of unbiased sex ratios. The polyandrous mating system will further reduce the effective population size in comparison to the census population (Nunney 1993), especially in the nivosus subspecies, which shows the highest rates of observed polygamy (Warriner et al. 1986; Eberhart-Phillips et al. 2017).

Overall, our results indicate a recent and substantial reduction in population size across snowy plover populations. Two of the demographic estimation methods we implemented (Msvar and Bottleneck) indicated that population size reduction has been pronounced in tenuirostris. This finding is supported by current population extirpations of tenuirostris on Caribbean islands (Brown 2012). Bottleneck did not find evidence of population reduction in occidentalis or nivosus subspecies, which could be because the program is best suited for detecting low magnitude population bottlenecks (Peery et al. 2012). Again, the power to detect bottlenecks depends on the number of loci analysed (Hoban et al. 2013).

During the past 1000 years, humans have dominated and profoundly altered global ecosystems (Vitousek et al. 1997; Barnosky et al. 2011; Ceballos et al. 2015) especially in coastal and island environments (Lotze et al. 2006; Spatz et al. 2017). The introduction of predators such as the nonnative red fox (Vulpes vulpes) and feral cats (Felis catus) plus other forms of human disturbance in coastal environments have led to reduced snowy plover breeding productivity and survival (Lafferty 2001; Ruhlen et al. 2003; Colwell et al. 2007; Webber et al. 2013; Dinsmore et al. 2017). Therefore, we hypothesise that reductions in snowy plover population size may have resulted from the combined impacts of increasing anthropogenic modification of habitats. Estimating demographic histories is becoming more common in conservation genetic studies (Carnaval et al. 2009; Palsbøll et al. 2013; Shafer et al. 2015; Stoffel et al. 2018) and can be used among other to prioritize conservation units (Stockwell et al. 2013).

\section{Implications for snowy plovers and future work}

Evidence of low and declining effective population size, combined with continued threats to snowy plovers highlight the vulnerable status of this species. Our understanding of this species is strongly reliant on studies from the nivosus subspecies, with little dedicated monitoring programs for tenuirostris and occidentalis populations. The demographic findings we present here and recent population extirpations occurring in tenuirostris (Brown 2012), provide strong justification for increased efforts at the Caribbean subspecies to halt the loss of genetic diversity and adaptive potential (Willi et al. 2006). In addition, basic monitoring of occidentalis breeding populations, such as those conducted by Wetlands International (Wetlands International 2019), are required to obtain reliable information on population trends.

Due to the high vagility and potential for gene flow among snowy plover populations, future work may benefit from population genomics based on whole genome sequence information with comprehensive sampling to focus on adaptive diversity in combination with actual movement data (e.g. GPS tagging) and range-wide demographic studies. This would allow us to fully characterise population connectivity and thus, infer conservation management units (Crandall et al. 2000; Fraser and Bernatchez 2001; Palsbøll et al. 2007; Lowe and Allendorf 2010; Funk et al. 2012; 
Flanagan et al. 2018). Our results suggest that eastern snowy plovers deserve a continuation of distinct conservation management, whereas we caution against immediate changes in management actions of the western nivosus deme such as delisting of the threatened Pacific distinct population segment. The high vagility and challenges provided by the unusual mating system in this species call for further work that should be based on an integrative approach using genomic, demographic, and movement, data to model population connectivity and viability.

Acknowledgements We are very grateful for all of the volunteers and field biologists who assisted with sample collection. Susan Haig kindly provided the single sample from California. Scott Edwards provided valuable advice during the conception of this study. We thank two anonymous reviewers for their constructive feedback which greatly improved our manuscript. This work was funded by a NERC GW4 + studentship NE/L002434/1 awarded to JDJ. Additional microsatellite genotyping of previously unpublished data sets was done at NBAF-Sheffield supported by grants (NBAF547, NBAF933, NBAF441). KHM was supported by a NERC GW4 + studentship NE/ L002434/1. TS was funded by a Royal Society Wolfson Merit Award (WM170050) and by the National Research, Development and Innovation Office of Hungary (ÉLVONAL KKP-126949, K-116310). CK was funded by the Max Planck Society. The authors declare no conflicts of interest.

Open Access This article is licensed under a Creative Commons Attribution 4.0 International License, which permits use, sharing, adaptation, distribution and reproduction in any medium or format, as long as you give appropriate credit to the original author(s) and the source, provide a link to the Creative Commons licence, and indicate if changes were made. The images or other third party material in this article are included in the article's Creative Commons licence, unless indicated otherwise in a credit line to the material. If material is not included in the article's Creative Commons licence and your intended use is not permitted by statutory regulation or exceeds the permitted use, you will need to obtain permission directly from the copyright holder. To view a copy of this licence, visit http://creativecommons.org/licenses/by/4.0/.

\section{References}

Aiello-Lammens ME, Akcakaya HR (2016) Using global sensitivity analysis of demographic models for ecological impact assessment. Conserv Biol 31:116-125

Aiello-Lammens ME, Chu-agor MAL, Convertino M, Fischer RA, Linkov I, Akçakaya HR (2011) The impact of sea-level rise on snowy plovers in Florida: integrating geomorphological, habitat, and metapopulation models. Glob Chang Biol 17:3644-3654

Allendorf FW, Hohenlohe PA, Luikart G (2010) Genomics and the future of conservation genetics. Nat Rev Genet 11:697-709

Altschul SF, Gish W, Miller W, Myers EW, Lipman DJ (1990) Basic local alignment search tool. J Mol Biol 215:403-410

American Ornithologist's Union (1957) Check-list of North American birds, 5th edn. American Ornithologist's Union, Washington, DC

Attard CRM, Beheregaray LB, Sandoval-Castillo J, Jenner KCS, Gill PC, Jenner M-NM, Morrice MG, Möller LM (2018) From conservation genetics to conservation genomics: a genome-wide assessment of blue whales (Balaenoptera musculus) in Australian feeding aggregations. R Soc Open Sci 5:170925
AviBase taxonomic concepts v.06 (2018) Snowy plover (Cuban) found on https://avibase.bsc-eoc.org/species.jsp?lang=EN\&aviba seid $=$ D38979BC5364C406\&sec $=$ summary. Accessed 27 June 2019

Baird NA, Etter PD, Atwood TS, Currey MC, Shiver AL, Lewis ZA, Selker EU, Cresko WA, Johnson EA (2008) Rapid SNP discovery and genetic mapping using sequenced RAD markers. PLoS ONE 3:e3376

Barnosky AD, Matzke N, Tomiya S, Wogan GOU, Swartz B, Quental TB, Marshall C, McGuire JL, Lindsey EL, Maguire KC, Mersey B, Ferrer EA (2011) Has the Earth's sixth mass extinction already arrived? Nature 471:51-57

Barth JMI, Damerau M, Matschiner M, Jentoft S, Hanel R (2017) Genomic differentiation and demographic histories of Atlantic and indo-pacific yellowfin tuna (Thunnus albacares) populations. Genome Biol Evol 9:1084-1098

Beaumont MA (1999) Detecting pop. Expansion and decline using microsatellites. Genetics 153:2013-2029

Beaumont MA (2010) Approximate Bayesian computation in evolution and ecology. Annu Rev Ecol Evol Syst 41:379-406

Beaumont MA, Zhang W, Balding DJ (2002) Approximate Bayesian computation in population genetics. Genetics 162:2025-2035

Brooks SP, Gelman A (1998) General methods for monitoring convergence of iterative simulations. J Comput Graph Stat 7:434-455

Brown AC (2012) Extirpation of the snowy plover on St. Martins. West Indies J Caribb Ornithol 25:31-34

Brüniche-Olsen A, Jones ME, Austin JJ, Burridge CP, Holland BR (2014) Extensive population decline in the Tasmanian devil predates European settlement and devil facial tumour disease. Biol Lett 10:20140619

Carmona-Isunza MC, Ancona S, Székely T, Ramallo-González A, Cruz-López M, Serrano-Meneses MA, Küpper C (2017) Adult sex ratio and operational sex ratio exhibit different temporal dynamics in the wild. Behav Ecol 28:523-532

Carnaval AC, Hickerson MJ, Haddad CFB, Rodrigues MT, Moritz C (2009) Stability predicts genetic diversity in the Brazilian Atlantic Forest hotspot. Science 323:785-790

Ceballos G, Ehrlich PR, Barnosky AD, García A, Pringle RM, Palmer TM (2015) Accelerated modern human-induced species losses: entering the sixth mass extinction. Sci Adv 1:e1400253

Chhatre VE, Emerson KJ (2017) StrAuto: automation and parallelization of STRUCTURE analysis. BMC Bioinformatics 18:192

Clarke AL, Saether B-E, Roskaft E (1997) Sex biases in avian dispersal: a reappraisal. Oikos 79:429-438

Clements JF, Schulenberg TS, Iliff MJ, Roberson D, Fredericks TA, Sullivan BL, Wood CL (2018) The eBird/clements checklist of birds of the world: v2018. https://www.birds.cornell.edu/cleme ntschecklist/download/. Accessed 27 June 2019

Cohen JB, Durkin MM, Zdravkovic M (2014) Human distubance of snowy plovers (Charadrius nivosus) in northwest Florida during the breeding season. Florida F Nat 42:1-44

Colwell M, Pearson W (2011) Four cases of inbreeding in a small population of the snowy plover. Wader Study Gr Bull 118:181-183

Colwell MA, Hurley S, Hall J, Dinsmore S (2007) Age-related survival and behavior of snowy plover chicks. Condor 109:638-647

Colwell MA, Feucht EJ, Lau MJ, Orluck DJ, Mcallister SE, Transou AN (2017) Recent snowy plover population increase arises from high immigration rate in coastal northern California. Wader Study 124:1-9

Convertino M, Elsner JB, Muñoz-Carpena R, Kiker GA, Martinez CJ, Fischer RA, Linkov I (2011) Do tropical cyclones shape shorebird habitat patterns? Biogeoclimatology of snowy plovers in Florida. PLoS ONE 6:e15683

Cornuet JM, Luikart G (1996) Power analysis of two tests for detecting recent population bottlenecks from allele frequency data. Genetics 144:2001-2014 
Crandall KA, Bininda-Emonds ORP, Mace GM, Wayne RK (2000) Considering evolutionary processess in conservation biology. Trends Ecol Evol 15:290-295

Cruz-López M, Eberhart-Phillips LJ, Fernández G, Beamonte-Barrientos R, Székely T, Serrano-Meneses MA, Küpper C (2017) The plight of a plover: viability of an important snowy plover population with flexible brood care in Mexico. Biol Conserv 209:440-448

D'Urban Jackson J, dos Remedios N, Maher KH, Zefania S, Haig S, Oyler-Mccance S, Blomqvist D, Burke T, Bruford MW, Székely T, Küpper C (2017) Polygamy slows down population divergence in shorebirds. Evolution 71:1-14

DaCosta JM, Sorenson MD (2014) Amplification biases and consistent recovery of loci in a double-digest RAD-seq protocol. PLoS ONE 9:e106713

del Hoyo J, Collar N, Kirwan GM, Sharpe CJ (2018) White-faced Plover (Charadrius dealbatus). In: del Hoyo J, Elliott A, Sargatal J, Christie DA, de Juana E (eds) Handbook of the birds of the world alive. Lynx Edicions, Barcelona. https://www.hbw.com/ node/467300. Accessed 28 July 2018

del Hoyo J, Collar N, Kirwan GM (2019) Snowy plover (Charadrius nivosus). In: del Hoyo J, Elliott A, Sargatal J, Christie DA, de Juana E (eds) Handbook of the birds of the world alive. Lynx Edicions, Barcelona. https://www.hbw.com/node/467301. Accessed 28 June 2019

Dieringer D, Schlötterer C (2003) MICROSATELLITE ANALYSER (MSA): a platform independent analysis tool for large microsatellite data sets. Mol Ecol Notes 3:167-169

Dinsmore SJ, Gaines EP, Pearson SF, Lauten DJ, Kathleen A, Dinsmore SJ, Gaines EP, Pearson SF, Lauten DJ, Castelein KA (2017) Factors affecting snowy plover chick survival in a managed population. Condor 119:34-43

dos Remedios N, Kupper C, Szekely T, Baker N, Versfeld W, Lee PLM (2017) Genetic isolation in an endemic African habitat specialist. Ibis 159:792-802

Doyle JM, Bell DA, Bloom PH, Emmons G, Fesnock A, Katzner TE, LaPré L, Leonard K, SanMiguel P, Westerman R, Andrew DeWoody J (2018) New insights into the phylogenetics and population structure of the prairie falcon (Falco mexicanus). BMC Genomics 19:1-14

Eberhart-Phillips LJ, Colwell MA (2014) Conservation challenges of a sink: the viability of an isolated population of the snowy plover. Bird Conserv Int 24:327-341

Eberhart-Phillips LJ, Küpper C, Miller TEX, Cruz-López M, Maher $\mathrm{KH}$, dos Remedios N, Stoffel MA, Hoffman JI, Krüger O, Székely T (2017) Sex-specific early survival drives adult sex ratio bias in snowy plovers and impacts mating system and population growth. Proc Natl Acad Sci 114:E5474-E5481

Edgar RC (2004a) MUSCLE: A multiple sequence alignment method with reduced time and space complexity. BMC Bioinform 5:1-19

Edgar RC (2004b) MUSCLE: Multiple sequence alignment with high accuracy and high throughput. Nucleic Acids Res 32:1792-1797

Edgar RC (2010) Search and clustering orders of magnitude faster than BLAST. Bioinformatics 26:2460-2461

Elliott-Smith E, Haig SM, Ferland CL, Gorman L (2004) Winter distribution and abundance of snowy plovers in eastern North America and the West Indies. Wader Study Group Bull 104:28-33

Evanno G, Regnaut S, Goudet J (2005) Detecting the number of clusters of individuals using the software STRUCTURE: a simulation study. Mol Ecol 14:2611-2620

Excoffier L, Foll M (2011) Fastsimcoal: a continuous-time coalescent simulator of genomic diversity under arbitrarily complex evolutionary scenarios. Bioinformatics 27:1332-1334

Excoffier L, Lischer HE (2010) Arlequin suite ver 3.5: a new series of programs to perform population genetics analyses under Linux and Windows. Mol Ecol Res 10:564-567
Excoffier L, Dupanloup I, Huerta-Sánchez E, Sousa VC, Foll M (2013) Robust demographic inference from genomic and SNP data. PLoS Genet 9:1003905

Feucht EJ, Colwell MA, Orluck NC et al (2017) Snowy plover breeding in coastal Northern California, Recovery Unit 2. Fish and wildlife service final report: 2017. https://www.fws.gov/arcata/ es/birds/WSP/documents/siteReports/California/2017\%20SNP L\%20Final\%20Report\%20RU2.pdf. Accessed 28 July 2018

Flanagan SP, Forester BR, Latch EK, Aitken SN, Hoban S (2018) Guidelines for planning genomic assessment and monitoring of locally adaptive variation to inform species conservation. Evol Appl 11:1035-1052

Francis RM (2017) pophelper: an R package and web app to analyse and visualize population structure. Mol Ecol Resour 17:27-32

Fraser D, Bernatchez L (2001) Adaptive evolutionary conservation: towards a unified concept for defining conservation units. Mol Ecol 10:2741-2752

Funk WC, Mullins TD, Haig SM, Mullins TD (2007) Conservation genetics of snowy plovers (Charadrius alexandrinus) in the Western Hemisphere: population genetic structure and delineation of subspecies. Conserv Genet 8:1287-1309

Funk WC, McKay JK, Hohenlohe PA, Allendorf FW (2012) Harnessing genomics for delineating conservation units. Trends Ecol Evol 27:489-496

Galindo-Espinosa D, Palacios E (2015) Estatus del chorlo nevado (Charadrius nivosus) en San Quintín y su disminución poblacional en la península de Baja California. Rev Mex Biodivers 86:789-798

Garrick RC, Kajdacsi B, Russello MA, Benavides E, Hyseni C, Gibbs JP, Tapia W, Caccone A (2015) Naturally rare versus newly rare: demographic inferences on two timescales inform conservation of Galápagos giant tortoises. Ecol Evol 5:676-694

Gelman A, Rubin D (1992) Inference from iterative simulation using multiple sequences. Stat Sci 7:457-511

Gill FB, Donsker D (2018) IOC world bird list (v8.2). https://doi. org/10.14344/IOC.ML.8.2. https://www.worldbirdnames.org/. Accessed 28 July 2018

Greenwood P (1980) Mating systems, philopatry and dispersal in birds and mammals. Anim Behav 28:1140-1162

Haig SM, Bronaugh WM, Crowhurst RS, Delia J, Eagles Smith CA, Epps CW, Knaus B, Miller MP, Moses ML, Oyler McCance S, Robinson WD, Sidlauskas B (2011) Genetic applications in avian conservation. Auk 128:205-229

Hall T (1999) BioEdit: a user-friendly biological sequence alignment editor and analysis program for Windows 95/98/NT. Nucleic Acids Symp Ser 41:95-98

Hardy OJ, Vekemans X (2002) spagedi: a versatile computer program to analyse spatial genetic structure at the individual or population levels. Mol Ecol Notes 2:618-620

Hoban SM, Gaggiotti OE, Bertorelle G (2013) The number of markers and samples needed for detecting bottlenecks under realistic scenarios, with and without recovery: a simulation-based study. Mol Ecol 22:3444-3450

Hubisz MJ, Falush D, Stephens M, Pritchard JK (2009) Inferring weak population structure with the assistance of sample group information. Mol Ecol Resour 9:1322-1332

Irwin DE (2018) Sex chromosomes and speciation in birds and other ZW systems. Mol Ecol 00:1-21. https://doi.org/10.1111/ mec. 14537

Janes JK, Miller JM, Dupuis JR, Malenfant RM, Gorrell JC, Cullingham CI, Andrew RL (2017) The K = 2 conundrum. Mol Ecol 26:3594-3602

Jombart T (2008) adegenet: a R package for the multivariate analysis of genetic markers. Bioinformatics 24:1403-1405

Kimura M, Ohta T (1973) The age of a neutral mutant persisting in a finite population. Genetics 75:199-212 
Kjeldsen SR, Zenger KR, Leigh K, Ellis W, Tobey J, Phalen D, Melzer A, FitzGibbon S, Raadsma HW (2016) Genome-wide SNP loci reveal novel insights into koala (Phascolarctos cinereus) population variability across its range. Conserv Genet 17:337-353

Kopelman NM, Mayzel J, Jakobsson M, Rosenberg NA, Mayrose I (2015) Clumpak: a program for identifying clustering modes and packaging population structure inferences across K. Mol Ecol Resour 15:1179-1191

Kumar S, Stecher G, Li M, Knyaz C, Tamura K (2018) MEGA X: molecular evolutionary genetics analysis across computing platforms. Mol Biol Evol 35:1547-1549

Küpper C, Burke T, Székely T, Dawson DA (2008) Enhanced crossspecies utility of conserved microsatellite markers in shorebirds. BMC Genomics 9:502

Küpper C, Augustin J, Kosztolányi A, Burke T, Figuerola J, Székely $\mathrm{T}$ (2009) Kentish versus snowy plover: phenotypic and genetic analyses of Charadrius alexandrinus reveal divergence of Eurasian and American subspecies. Auk 126:839-852

Küpper C, Aguilar E, Gonzalez O (2011) Notas sobre la ecología reproductiva y conservación de los chorlos nevados Charadrius nivosus occidentalis en Paracas, Perú. Rev Per Biol 18:91-96

Küpper C, Edwards SV, Kosztolányi A, Alrashidi M, Burke T, Herrmann P, Argüelles-Tico A, Amat JA, Amezian M, Rocha A, Hötker H, Ivanov A, Chernicko J, Székely T (2012) High gene flow on a continental scale in the polyandrous Kentish plover Charadrius alexandrinus. Mol Ecol 21:5864-5879

Lafferty KD (2001) Disturbance to wintering western snowy plovers. Biol Conserv 101:315-325

Lafferty KD, Goodman D, Sandoval CP (2006) Restoration of breeding by snowy plovers following protection from disturbance. Biodivers Conserv 15:2217-2230

Lamonte KM, Douglass NJ, Himes JG, Wallace GE (2002) Status and distribution of the snowy plover in Florida. 2002 study final report. Florida Fish \& Wildlife Conservation Commission, Tallahassee. https://www.flshorebirdalliance.org/media/11444/Lamon te_Douglass-2002_SNPL_Report.pdf. Accessed 28 July 2018

Leigh JW, Bryant D (2015) POPART: full-feature software for haplotype network construction. Methods Ecol Evol 6:1110-1116

Lemay MA, Russello MA (2015) Genetic evidence for ecological divergence in kokanee salmon. Mol Ecol 24:798-811

Librado P, Rozas J (2009) DnaSP v5: a software for comprehensive analysis of DNA polymorphism data. Bioinformatics 25:1451-1452

Linck EB, Battey CJ (2017) Minor allele frequency thresholds strongly affect population structure inference with genomic datasets. bioRxiv. https://doi.org/10.1101/188623

Loiselle BA, Sork VL, Nason J, Graham C (1995) Spatial genetic structure of a tropical understory shrub, Psychotria officinalis (Rubiaceae ). Am J Bot 82:1420-1425

Lotze HK, Lenihan HS, Bourque BJ, Bradbury RH, Cooke RG, Kay MC, Kidwell SM, Kirby MX, Peterson CH, Jackson JBC (2006) Depletion, degradation, and recovery potential of estuaries and coastal seas. Science 312:1806-1810

Lowe WH, Allendorf FW (2010) What can genetics tell us about population connectivity? Mol Ecol 19:3038-3051

Malinsky M, Trucchi E, Lawson DJ, Falush D (2018) RADpainter and fineRADstructure: population inference from RADseq data. Mol Biol Evol 35:1284-1290

Mank JE, Axelsson E, Ellegren H (2007) Fast-X on the Z: rapid evolution of sex-linked genes in birds. Genome Res 17:618-624

Mason NA, Taylor SA (2015) Differentially expressed genes match bill morphology and plumage despite largely undifferentiated genomes in a Holarctic songbird. Mol Ecol 24:3009-3025
Medina I, Cooke GM, Ord TJ (2018) Walk, swim or fly? Locomotor mode predicts genetic differentiation in vertebrates. Ecol Lett 21:638-645

Meirmans PG (2014) Nonconvergence in Bayesian estimation of migration rates. Mol Ecol Resour 14:726-733

Meisel RP, Connallon T (2013) The faster-X effect: integrating theory and data. Trends Genet 29:537-544

Miller MR, Dunham JP, Amores A, Cresko WA, Johnson EA (2007) Rapid and cost-effective polymorphism identification and genotyping using restriction site associated DNA (RAD) markers. Genome Res 17:240-248

Miller MMP, Haig SSM, Gratto-Trevor CLC, Mullins TDT (2010) Subspecies status and population genetic structure in Piping Plover (Charadrius melodus). Auk 127:57-71

Miller MP, Haig SM, Mullins TD, Ruan L, Casler B, Dondua A, Gates HR, Johnson JM, Kendall S, Tomkovich PS, Tracy D, Valchuk OP, Lanctot RB (2015) Intercontinental genetic structure and gene flow in Dunlin (Calidris alpina), a potential vector of avian influenza. Evol Appl 8:149-171

Moritz C (1994) Defining "evolutionarily significant units" for conservation. Trends Ecol Evol 9:373-375

Mullin SM, Colwell MA, McAllister SE, Dinsmore SJ (2010) Apparent survival and population growth of snowy plovers in coastal Northern California. J Wildl Manag 74:1792-1798

Novembre J, Stephens M (2008) Interpreting principal components analyses of spatial population genetic variation. Nat Genet 40:646-649

Nunney L (1993) The influence of mating system and overlapping generations on effective population size. Evolution 47:1329-1341

Ottvall R, Höglund J, Bensch S, Larsson K (2005) Population differentiation in the redshank (Tringa totanus) as revealed by mitochondrial DNA and amplified fragment length polymorphism markers. Conserv Genet 6:321-331

Oyler-McCance SJ, John JS, Kysela RF, Knopf FL (2008) Population structure of mountain plover as determined using nuclear microsatellites. Condor 110:493-499

Page GW, Stenzel LE, Shuford WD, Bruce CR (1991) Distribution and abundance of the snowy plover on its western North American breeding grounds. J Field Ornithol 62:245-255

Page GW, Stenzel LE, Warriner JS, Warriner JC, Paton PW (2009) Snowy plover Charadrius nivosus. In: Poole AF (ed) Birds of North America. Cornell Lab of Ornithology, Ithaca.

Palsbøll PJ, Bérubé M, Allendorf FW (2007) Identification of management units using population genetic data. Trends Ecol Evol 22:11-16

Palsbøll PJ, Peery ZM, Olsen MT, Beissinger SR, Bérubé M (2013) Inferring recent historic abundance from current genetic diversity. Mol Ecol 22:22-40

Paton PWC, Edwards TC (1996) Factors affecting interannual movements of snowy plovers. Auk 113:534-543

Peakall R, Smouse PE (2012) GenAlEx 6.5: genetic analysis in Excel. Population genetic software for teaching and research-an update. Bioinformatics 28:2537-2539

Pearson WJ, Colwell MA (2014) Effects of nest success and mate fidelity on breeding dispersal in a population of snowy plovers Charadrius nivosus. Bird Conserv Int 24:342-353

Peery ZM, Kirby R, Reid BN, Stoelting R, Doucet-Bëer E, Robinson S, Vásquez-Carrillo C, Pauli JN, Palsboll PJ (2012) Reliability of genetic bottleneck tests for detecting recent population declines. Mol Ecol 21:3403-3418

Peters JL, Lavretsky P, DaCosta JM, Bielefeld RR, Feddersen JC, Sorenson MD (2016) Population genomic data delineate conservation units in mottled ducks (Anas fulvigula). Biol Conserv 203:272-281 
Pfeifer B, Wittelsbu U, Ramos-Onsins SE, Lercher MJ (2014) PopGenome: an efficient Swiss Army knife for population genomic analyses in R. Mol Biol Evol 31:1929-1936

Piry S, Luikart G, Cornuet JM (1999) BOTTLENECK: a computer program for detecting recent reductions in the effective size using allele frequency data. J Hered 90:502-503

Powell AN, Collier CL (2011) Habitat use and reproductive success of western snowy plovers at new nesting areas created for California. J Wildl Manag 64:24-33

Prince DJ, O'Rourke SM, Thompson TQ, Ali OA, Lyman HS, Saglam IK, Hotaling TJ, Spidle AP, Miller MR (2017) The evolutionary basis of premature migration in Pacific salmon highlights the utility of genomics for informing conservation. Sci Adv 3:e1603198

Pritchard JK, Stephens M, Donnelly P (2000) Inference of population structure using multilocus genotype data. Genetics 155:945-959

Quinto-Cortés CD, Woerner AE, Watkins JC, Hammer MF (2018) Modeling SNP array ascertainment with approximate Bayesian computation for demographic inference. Sci Rep 8:1-10

R Development Core Team (2019) R: a language and environment for statistical computing. R Foundation for Statistical Computing, Vienna

Rambaut A, Drummond AJ, Xie D, Baele G, Suchard MA (2018) Posterior summarisation in Bayesian phylogenetics using Tracer 1.7. Syst Biol. https://doi.org/10.1093/sysbio/syy032

Rannala B (2015) BayesAss edition 3.0 user's manual. University of California, Davis

Rheindt FE, Székely T, Edwards SV, Lee PLM, Burke T, Kennerley PR, Bakewell DN, Alrashidi M, Kosztolányi A, Weston MA, Liu W-TT, Lei W-PP, Shigeta Y, Javed S, Zefania S, Küpper C, Peter R, Rheindt FE, Székely T, Edwards SV, Lee PLM, Burke T, Kennerley PR, Bakewell DN, Alrashidi M, Kosztolányi A, Weston MA, Liu W-TT, Lei W-PP, Shigeta Y, Javed S, Zefania S, Küpper C (2011) Conflict between genetic and phenotypic differentiation: the evolutionary history of a "lost and rediscovered" shorebird. PLoS ONE 6:e26995

Rönkä N, Kvist L, Pakanen V-M, Rönkä A, Degtyaryev V, Tomkovich P, Tracy D, Koivula K (2012) Phylogeography of the Temminck's Stint (Calidris temminckii): historical vicariance but little present genetic structure in a regionally endangered Palearctic wader. Divers Distrib 18:704-716

Ruegg KC, Anderson EC, Paxton KL, Apkenas V, Lao S, Siegel RB, DeSante DF, Moore F, Smith TB (2014) Mapping migration in a songbird using high-resolution genetic markers. Mol Ecol 23:5726-5739

Ruhlen TD, Abbott S, Stenzel LE, Page GW (2003) Evidence that human disturbance reduces snowy plover chick survival. $\mathrm{F}$ Ornithol 74:300-304

Sadanandan K, Küpper C, Low GW, Yao CT, Li Y, Xu T, Rheindt FE, Wu S (2019) Population divergence and gene flow in two East Asian shorebirds on the verge of speciation. Sci Rep 9:8546

Saenz-Agudelo P, DiBattista JD, Piatek MJ, Gaither MR, Harrison HB, Nanninga GB, Berumen ML (2015) Seascape genetics along environmental gradients in the Arabian Peninsula: insights from ddRAD sequencing of anemonefishes. Mol Ecol 24:6241-6255

Sambrook J, Russell D (2006) Purification of nucleic acids by extraction with phenol:chloroform. Cold Spring Harb Protoc. https:// doi.org/10.1101/pdb.prot093450

Shafer ABA, Gattepaille LM, Stewart REA, Wolf JBW (2015) Demographic inferences using short-read genomic data in an approximate Bayesian computation framework: in silico evaluation of power, biases and proof of concept in Atlantic walrus. Mol Ecol 24:328-345

Smith BJ (2007) boa: an R package for MCMC output convergence. J Stat Softw 21:1-37
Spatz DR, Zilliacus KM, Holmes ND, Butchart SHM, Genovesi P, Ceballos G, Tershy BR, Croll DA (2017) Globally threatened vertebrates on islands with invasive species. Sci Adv 3:e1603080

Stenzel L, Warriner J, Warriner J (1994) Long-distance breeding dispersal of snowy plovers in western North America. J Anim Ecol 63:887-902

Stenzel LE, Page GW, Warriner JC, Warriner JS, George DE, Eyster CR, Ramer BA, Neuman KK (2007) Survival and natal dispersal of juvenile snowy plovers (Charadrius alexandrinus) in central coastal California. Auk 124:1023-1036

Stenzel LE, Page GW, Warriner JC, Warriner JS, Neuman KK, George DE, Eyster CR, Bidstrup FC (2011) Male-skewed adult sex ratio, survival, mating opportunity and annual productivity in the snowy plover Charadrius alexandrinus. Ibis 153:312-322

Stockwell CA, Heilveil JS, Purcell K (2013) Estimating divergence time for two evolutionarily significant units of a protected fish species. Conserv Genet 14:215-222

Stoffel MA, Humble E, Acevedo-Whitehouse K, Chilvers BL, Dickerson B, Galimberti F, Gemmell N, Goldsworthy S, Nichols Krüger O, Negro S, Osborne A, Paijmans AJ, Pastor T, Robertson BC, Sanvito S, Schultz J, Shafer ABA, Wolf JBW, Hoffman JI (2018) Recent demographic histories and genetic diversity across pinnipeds are shaped by anthropogenic interactions and mediated by ecology and life-history. bioRxiv. https://doi.org/10.1101/293894

Storz JF, Beaumont MA (2002) Testing for genetic evidence of population expansion and contraction: an empirical analysis of microsatellite DNA variation using a hierarchical Bayesian model. Evolution 56:154-166

Tamura K, Nei M, Kumar S (2004) Prospects for inferring very large phylogenies by using the neighbor-joining method. Proc Natl Acad Sci 101:11030-11035

Templeton AR, Crandall KA, Sing CF (1992) A cladistic analysis of phenotypic associations with haplotypes inferred from restriction endonuclease mapping and DNA sequence data. III. Cladogram estimation. Genetics 132:619-633

Thomas SM, Lyons JE, Andres BA, T-Smith EE, Palacios E, Cavitt JF, Andrew-Royle J, Fellows SD, Maty K, Howe WH, Mellink E, Melvin S, Zimmerman T (2012) Population size of snowy plovers breeding in North America. Waterbirds 35:1-14

United States Fish and Wildlife Service (2011) Endangered and threatened wildlife and plants; 90-day finding on a petition to list the snowy plover and reclassify the wintering population of piping plover. Federal Register. 2011-22900. https://www.federalreg ister.gov/documents/2011/09/08/2011-22900/endangered-andthreatened-wildlife-and-plants-90-day-finding-on-a-petition-tolist-the-snowy-plover.

Vendrami DLJ, Telesca L, Weigand H, Weiss M, Fawcett K, Lehman K, Clark MS, Leese F, McMinn C, Moore H, Hoffman JI (2017) RAD sequencing resolves fine-scale population structure in a benthic invertebrate: implications for understanding phenotypic plasticity. R Soc Open Sci 4:160548

Verkuil YI, Piersma T, Jukema J, Hooijmeijer JCEW, Zwarts L, Baker AJ (2012) The interplay between habitat availability and population differentiation: a case study on genetic and morphological structure in an inland wader (Charadriiformes). Biol J Linn Soc 106:641-656

Vitousek PM, Mooney HA, Lubchenco J, Melillo JM (1997) Human domination of earth's ecosystems. Science 277:494-499

Wang J, Santiago E, Caballero A (2016) Prediction and estimation of effective population size. Heredity 117:193-206

Wang X, Maher KH, Zhang N, Que P, Zheng C, Liu S, Wang B, Huang Q, Chen D, Yang X, Zhang Z, Székely T, Urrutia A, Liu Y (2019) Demographic histories and genome-wide patterns of divergence in incipient species of shorebirds. BioRixv. https:// doi.org/10.1101/559633 
Warriner J, Warriner J, Page G, Stenzel L (1986) Mating system and reproductive success of a small population of polygamous snowy plovers. Wilson Bull 98:15-37

Webber AF, Heath JA, Fischer RA (2013) Human disturbance and stage-specific habitat requirements influence snowy plover site occupancy during the breeding season. Ecol Evol 3:853-863

Wegmann D, Leuenberger C, Neuenschwander S, Excoffier L (2010) ABCtoolbox: a versatile toolkit for approximate Bayesian computations. BMC Bioinform 11:116

Wetlands International (2019) Waterbird population estimates. https:// wpe.wetlands.org. Accessed 2 July 2019

Willi Y, Van Buskirk J, Hoffmann AA (2006) Limits to the adaptive potential of small populations. Annu Rev Ecol Evol Syst 37:433-458

Wilson GA, Rannala B (2003) Bayesian inference of recent migration rates using multilocus genotypes. Genetics 163:1177-1191

Younger JL, Clucas GV, Kao D, Rogers AD, Gharbi K, Hart T, Miller KJ (2017) The challenges of detecting subtle population structure and its importance for the conservation of emperor penguins. Mol Ecol 26:3883-3897

Zhang G, Li C, Li Q, Li B, Larkin DM, Lee C, Storz JF, Antunes A, Greenwold MJ, Meredith RW, Ödeen A, Cui J, Zhou Q, Xu L, Pan H, Wang Z, Jin L, Zhang P, Hu H, Yang W, Hu J, Xiao J,
Yang Z, Liu Y, Xie Q, Yu H, Lian J, Wen P, Zhang F, Li H, Zeng Y, Xiong Z, Liu S, Zhou L, Huang Z, An N, Wang J, Zheng Q, Xiong Y, Wang G, Wang B, Wang J, Fan Y, da Fonseca RR, Alfaro-Núñez A, Schubert M, Orlando L, Mourier T, Howard JT, Ganapathy G, Pfenning A, Whitney O, Rivas MV, Hara E, Smith J, Farré M, Narayan J, Slavov G, Romanov MN, Borges R, Machado JP, Khan I, Springer MS, Gatesy J, Hoffmann FG, Opazo JC, Håstad O, Sawyer RH, Kim H, Kim KW, Kim HJ, Cho S, Li N, Huang Y, Bruford MW, Zhan X, Dixon A, Bertelsen MF, Derryberry E, Warren W, Wilson RK, Li S, Ray DA, Green RE, O'Brien SJ, Griffin D, Johnson WE, Haussler D, Ryder OA, Willerslev E, Graves GR, Alström P, Fjeldså J, Mindell DP, Edwards SV, Braun EL, Rahbek C, Burt DW, Houde P, Zhang Y, Yang H, Wang J, Jarvis ED, Gilbert MT, Wang J, Avian Genome Consortium, Jarvis ED, Gilbert MT, Wang J (2014) Comparative genomics reveals insights into avian genome evolution and adaptation. Science 346:1311-1321

Zhou Q, Zhang J, Bachtrog D, An N, Huang Q, Jarvis ED, Gilbert MTP, Zhang G (2014) Complex evolutionary trajectories of sex chromosomes across bird taxa. Science 346:1246338

Publisher's Note Springer Nature remains neutral with regard to jurisdictional claims in published maps and institutional affiliations.

\section{Affiliations}

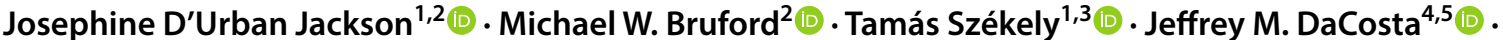

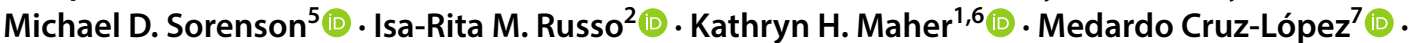 Daniel Galindo-Espinosa ${ }^{8}$. Eduardo Palacios ${ }^{9}$ - . Atahualpa Eduardo De Sucre-Medrano ${ }^{10}$. John Cavitt ${ }^{11}$. Raya Pruner ${ }^{12}$ - Alcides L. Morales ${ }^{13} \cdot$ Oscar Gonzalez $^{14,15}$ (D) Terry Burke $^{6}\left(\mathbb{C}^{-} \cdot\right.$ Clemens Küpper $^{16}$}

1 Milner Centre for Evolution, Department of Biology and Biochemistry, University of Bath, Bath BA2 7AY, UK

2 Organisms and Environment Division, Cardiff School of Biosciences, Cardiff University, Cardiff CF10 3AX, UK

3 Maio Biodiversity Foundation, Maio, Republic of Cabo Verde

4 Biology Department, Boston College, Chestnut Hill, MA 02467, USA

5 Department of Biology, Boston University, Boston, MA 02215, USA

6 NERC-Biomolecular Analysis Facility, Department of Animal and Plant Sciences, University of Sheffield, Western Bank, Sheffield S10 2TN, UK

7 Posgrado de Ciencias del Mar y Limnología, Unidad Académica Mazatlán, Universidad Nacional Autónoma de México, Unidad Académica Mazatlán, Sinaloa, Mexico

8 Departamento Académico de Ciencias Marinas y Costeras, Universidad Autónoma de Baja California Sur, Baja California Sur, A.P. 19-B, 23080 La Paz, Mexico
9 Centro de Investigación Científica y de Educación Superior de Ensenada, Baja California Sur, Unidad La Paz, Miraflores 334, Col. Bella Vista, 23050 La Paz, Mexico

10 Laboratorio de Zoología, Facultad de Estudios Superiores Iztacala, Universidad Nacional Autónoma de México, Tlalnepantla, Mexico

11 Avian Ecology Laboratory, Department of Zoology, Weber State University, Ogden, UT, USA

12 Florida Fish and Wildlife Conservation Commission, Fish and Wildlife Research Institute, Panama City, FL, USA

13 Fideicomiso de Conservación de Puerto Rico, Para La Naturaleza, P.O. Box 9023554, San Juan, Puerto Rico

14 Grupo Aves del Perú, Gómez del Carpio 135, Barrio Medico, Lima 34, Peru

15 Department of Natural Sciences, Emmanuel College, Franklin Springs, GA 30369, USA

16 Max Planck Institute for Ornithology, Eberhard Gwinner Str., 82319 Seewiesen, Germany 